\title{
The impact of cow's milk-mediated mTORC1- signaling in the initiation and progression of prostate cancer
}

\author{
Bodo C Melnik ${ }^{1 *}$, Swen Malte John ${ }^{1}$, Pedro Carrera-Bastos ${ }^{2}$ and Loren Cordain ${ }^{3}$
}

\begin{abstract}
Prostate cancer (PCa) is dependent on androgen receptor signaling and aberrations of the PI3K-Akt-mTORC1 pathway mediating excessive and sustained growth signaling. The nutrient-sensitive kinase mTORC1 is upregulated in nearly $100 \%$ of advanced human PCas. Oncogenic mTORC1 signaling activates key subsets of mRNAs that cooperate in distinct steps of PCa initiation and progression. Epidemiological evidence points to increased dairy protein consumption as a major dietary risk factor for the development of PCa. MTORC1 is a master regulator of protein synthesis, lipid synthesis and autophagy pathways that couple nutrient sensing to cell growth and cancer. This review provides evidence that PCa initiation and progression are promoted by cow's milk, but not human milk, stimulation of mTORC1 signaling. Mammalian milk is presented as an endocrine signaling system, which activates mTORC1, promotes cell growth and proliferation and suppresses autophagy. Naturally, milk-mediated mTORC1 signaling is restricted only to the postnatal growth phase of mammals. However, persistent consumption of cow's milk proteins in humans provide highly insulinotropic branched-chain amino acids (BCAAs) provided by milk's fast hydrolysable whey proteins, which elevate postprandial plasma insulin levels, and increase hepatic IGF-1 plasma concentrations by casein-derived amino acids. BCAAs, insulin and IGF-1 are pivotal activating signals of mTORC1. Increased cow's milk protein-mediated mTORC1 signaling along with constant exposure to commercial cow's milk estrogens derived from pregnant cows may explain the observed association between high dairy consumption and increased risk of PCa in Westernized societies. As well-balanced mTORC1-signaling plays an important role in appropriate prostate morphogenesis and differentiation, exaggerated mTORC1-signaling by high cow's milk consumption predominantly during critical growth phases of prostate development and differentiation may exert long-term adverse effects on prostate health. Attenuation of mTORC1 signaling by contemporary Paleolithic diets and restriction of dairy protein intake, especially during mTORC1-dependent phases of prostate development and differentiation, may offer protection from the most common dairy-promoted cancer in men of Western societies.
\end{abstract}

Keywords: Cancer prevention, Dairy, Estrogens, IGF-1, Insulin, Leucine, Metformin, Milk signaling, Morphogenesis, mTORC1, Prostate cancer

\section{Introduction}

Prostate cancer ( $\mathrm{PCa}$ ) is the most commonly diagnosed malignancy in males living in highly developed and industrialized countries of Europe and North America. In these Western countries high PCa incidence rates between 80 and 100 per 100,000 per year are observed,

\footnotetext{
* Correspondence: Melnik@t-online.de

${ }^{1}$ Department of Dermatology, Environmental Medicine and Health Theory, University of Osnabrück, Sedanstrasse 115, Osnabrück D-49090, Germany Full list of author information is available at the end of the article
}

while incidence rates of $\mathrm{PCa}$ in western, southeastern and eastern Asia and eastern and northern Africa range between 10 and 20 per 100,000 per year [1]. There were an estimated 217,730 new PCa diagnoses and 32,050 deaths in the United States during 2010, which makes PCa the second leading cause of cancer death in men. Several lines of evidence confirmed that Western diet is related to PCa risk and outcome [2-5]. In addition, per capita consumption of milk and dairy products correlates positively with both $\mathrm{PCa}$ incidence and mortality $[6,7]$.

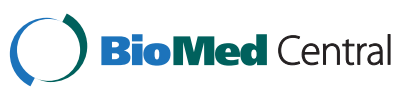




\section{Epidemiological association between dairy protein consumption and prostate cancer}

Diets of wealthy well-developed countries are characterized by high dairy protein and meat consumption. In Japan the mortality of PCa increased 25-fold linearly after World War 2 associated with an increase in the intake of milk (20-fold), meat (9-fold) and eggs (7-fold), respectively [8]. The Health Professionals Study demonstrated a strong association between calcium intake and prostate cancer risk [9]. Dairy proteins are a significant dietary source of calcium. In Western diets, dairy protein-associated calcium is predominantly provided by high and increasing consumption of cheese exemplified by the per capita cheese consumption in Germany from 1935 to 2011 (Figure 1). Whereas, Giovannucci et al. [9] suggested that high calcium intake might increase prostate carcinogenesis by lowering serum concentrations of 1,25-dihydroxyvitamin $\mathrm{D}\left[1,25(\mathrm{OH})_{2} \mathrm{D}\right]$, they could not exclude a role of "additional cancer-promoting factors in the nonfat component" of dairy products. The European Prospective Investigation into Cancer and Nutrition examined animal food, protein and calcium consumption and the risk of PCa in 142,251 men during an 8.7year prospective study period and confirmed a strong association between high intake of dairy protein and increased risk of $\mathrm{PCa}$ [10]. An increase of $35 \mathrm{~g} /$ day in consumption of dairy protein was associated with an increase in the risk of PCa of $32 \%$ [10].

Remarkably, calcium from dairy products was positively associated with PCa risk, but not calcium from other foods [10]. This observation questions the role of dairy-derived calcium and points to a more critical role of the milk protein fraction itself. In fact, Ahn et al. [11] found no association between calcium intake and serum concentrations of 25-hydroxy-vitamin D [25(OH)D] and
$1,25(\mathrm{OH})_{2} \mathrm{D}$. Moreover, the calcium-vitamin-D hypothesis has been challenged at the level of cell biology by Heaney [12]. Thus, recent lines of evidence do not support the formerly suggested "high calcium intake/low vitamin D hypothesis" of dairy-mediated prostate tumorigenesis [9]. In this paper, evidence will be provided that the intrinsic signaling capability of the dairy protein itself is the most critical nutritional factor linking milk and dairy products to the pathogenesis of PCa.

Several ecological, cohort and case control studies conducted in various countries [6,8-11,13-21] have provided evidence for the association between increased milk and dairy intake and increased risk of $\mathrm{PCa}$, which has been confirmed by meta-analyses and systematic reviews [22-25]. However, two studies, the prospective cohort study of Rodriguez et al. [26] and the meta-analysis of Huncharek et al. [27], did not find an association between dairy product intake and increased risk of PCa. In contrast, Raimondi et al. [21] recently reported a two-fold increased risk of PCa associated with high intakes of dairy products. Ganmaa et al. [6] have analyzed the incidence and mortality rates of $\mathrm{PCa}$ in 42 countries and identified "milk + cheese" as a major risk constellation contributing to the mortality from PCa. Notably, populations with low dairy protein intake like the Inuit and Alaska native men exhibit an extremely low incidence and mortality rate of PCa [28,29]. It is alarming, that daily milk consumption in adolescence has recently been associated with a 3.2-fold risk of advanced PCa in adulthood [30]. Notably, milk and dairy consumption has been linked to an increased incidence of acne in adolescence [31-35]. Severe acne in adolescence has been related to an increased risk of $\mathrm{PCa}$ in adulthood [36]. The association between PCa and acne might already point to overstimulated mTORC1-

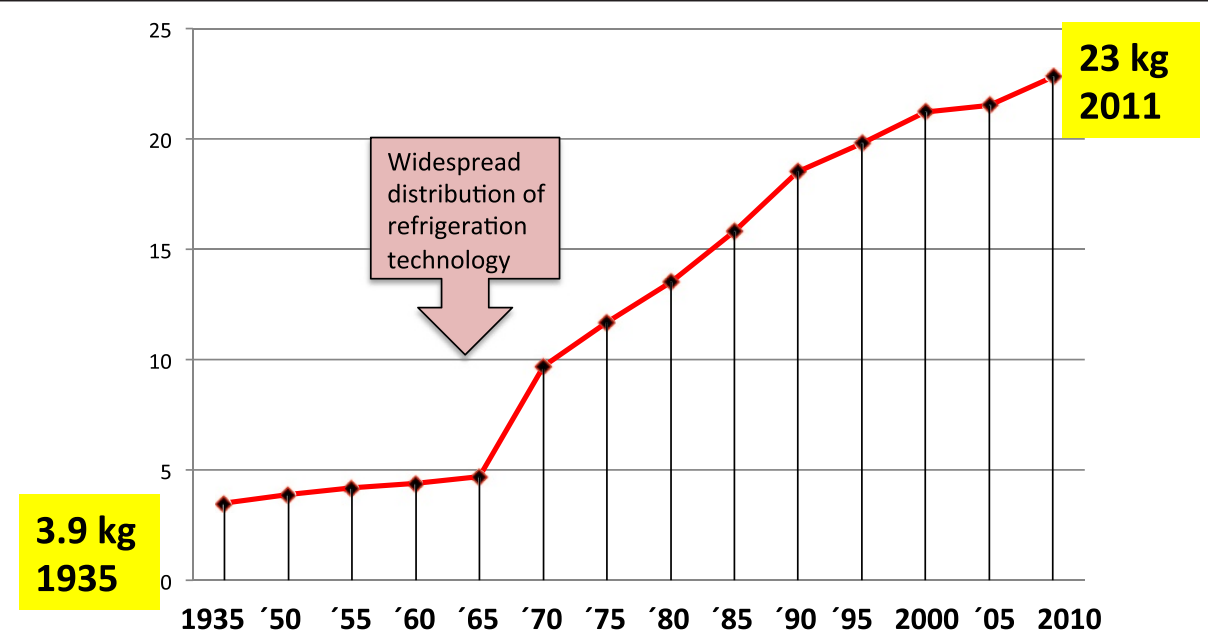

Figure 1 Annual increase of per capita cheese consumption in Germany. Cheese is a rich source of the mTORC1-activating amino acid leucine. Cheese consumption steadily increased in industrialized countries like Germany. 
signaling of the androgen-dependent sebaceous gland and prostate gland during puberty as the underlying common cause of aberrant signal transduction [37].

As the majority of controlled studies have shown a dose-related association between dairy protein intake and increased risk of $\mathrm{PCa}$, the underlying mechanism of dairy-induced $\mathrm{PCa}$ has not yet been identified. The calcium hypothesis $[9,38]$, however, does not explain the cancer promoting effects of dairy protein intake as nondairy-derived calcium showed no relation to an increased risk of PCa [10]. Neither intake of calcium from dairy products nor calcium supplements were associated with PCa risk in a prospective study of Koh et al. [39]. Neither high calcium nor high phosphate intake of dairy products have been shown to change intracellular concentrations of $1,25(\mathrm{OH})_{2} \mathrm{D}$ in PCa cells. Intracellular $1,25(\mathrm{OH})_{2} \mathrm{D}$ concentrations are primarily regulated by intracellular synthesis and not by $1,25(\mathrm{OH})_{2} \mathrm{D}$ uptake from the circulation [12]. Thus, neither the calcium hypothesis [38] nor the phosphorus hypothesis of $\mathrm{PCa}$ [40] provide reasonable tumorigenic mechanisms compatible with recent insights into the molecular biology of vitamin D, which could explain the proliferative cellular effects of dairy intake, thus calling both hypotheses of PCa into question. It is the major purpose of this paper to provide evidence that dairy protein-derived amino acids provide the cancer-promoting effect of dairy by introducing mammalian milk as a fundamental growthpromoting mTORC1-signaling system of mammalian evolution.

\section{Evidence for cows'milk growth-stimulatory effects on prostate cancer}

Organic cows' milk, digested in vitro, stimulated the growth of LNCaP prostate cancer cells in each of 14 separate experiments, producing an average increase in growth rate of over 30\% [41]. Remarkably, isolated addition of digested purified casein had a less stimulatory effect on LNCaP cell proliferation than whole cow' s milk [41]. This observation implies that the hormonal compounds of commercial cows milk like estrogens and IGF-1 are not the exclusive stimuli of milk-induced PCa cell growth, but rather points to the role of amino acids derived from hydrolysed milk proteins. This in vitro evidence fits well with recent epidemiological data from a cohort of 3,918 men diagnosed with apparently localized PCa. In this cohort, high versus low intakes of whole milk substantially increased the risk of PCa progression [42]. To understand the biological impact of milk in prostate tumorigenesis, the signal transduction pathways driven by mammalian milk, an mTORC1-signaling system naturally confined to the neonatal growth period, must be examined in greater detail.
mTORC1: the convergence point of nutrient-derived and milk-mediated signaling

Milk signaling is integrated and mediated by the nutrientsensitive kinase mTORC1 (mammalian target of rapamycin complex 1). mTORC1 links amino acid, growth factor, and energy availability to prostate epithelial cell growth, proliferation, motility, autophagy, morphogenesis and tumorigenesis. The mTORC1 signaling pathway has become a major focus of human cancer research [43]. It is thus of utmost importance to understand the nutrientmediated signaling pathways regulating mTORC1, the central hub controlling cell signaling, cell growth and cell proliferation.

mTORC1 signaling stimulates gene transcription, translation, ribosome biogenesis, protein synthesis, insulin synthesis, cell growth, cell proliferation, lipid synthesis but suppresses mechanisms of autophagy [44-49]. mTOR is a multi-domain protein of approximately $300 \mathrm{kDa}$ exhibiting a protein kinase domain at its C-terminus related to phosphoinositol-3-kinases (PI3Ks). In mammalian cells two functionally different mTOR complexes exist: $m$ TORC1 and $m$ TORC2. Among other functional proteins, mTORC1 contains the important partner protein Raptor, which interacts with substrates for mTORC1-mediated phosphorylation like p70 S6 kinase 1 (S6K1). mTORC1 controls the impact of nutrientderived signals on the $G_{1} / S$ transition and $G_{2} / M$ progression of the cell cycle [46]. In contrast to mTORC2, which contains the partner protein Rictor, only mTORC1 plays a special role in sensing cellular nutrients, amino acids, and energy (ATP) levels, which are important stimuli for cell growth and proliferation. Liver kinase B1 (LKB1) and AMP-activated protein kinase (AMPK) are further critical regulators of mTORC1 [50]. Most functions of mTORC1 are inhibited by rapamycin, a triene macrolide antibiotic synthesized by Streptomyces hygroscopicus [51].

\section{Pivotal role of the essential amino acid leucine for mTORC1 activation}

mTORC1 activation is critically dependent on the availability of sufficient amounts of amino acids, especially of the branched-chain essential amino acid (BCAA) leucine [52-54] (Figure 2). Recent advances in molecular biology have elucidated two parallel mechanisms of mTORC1 activation: 1) the upstream activation of the small GTPase Rheb (Ras homolog enriched in brain) by growth factor signals (insulin, IGF-1, PDGF) and high cellular energy levels (glucose, ATP), and 2) the amino acid-dependent translocation of inactive mTORC1 to active Rheb localized at late endosome or lysosome compartments [53-56] (Figure 2). The activity of Rheb is tightly regulated by the tuberous sclerosis proteins TSC1 (hamartin) and TSC2 (tuberin), which form a functional 


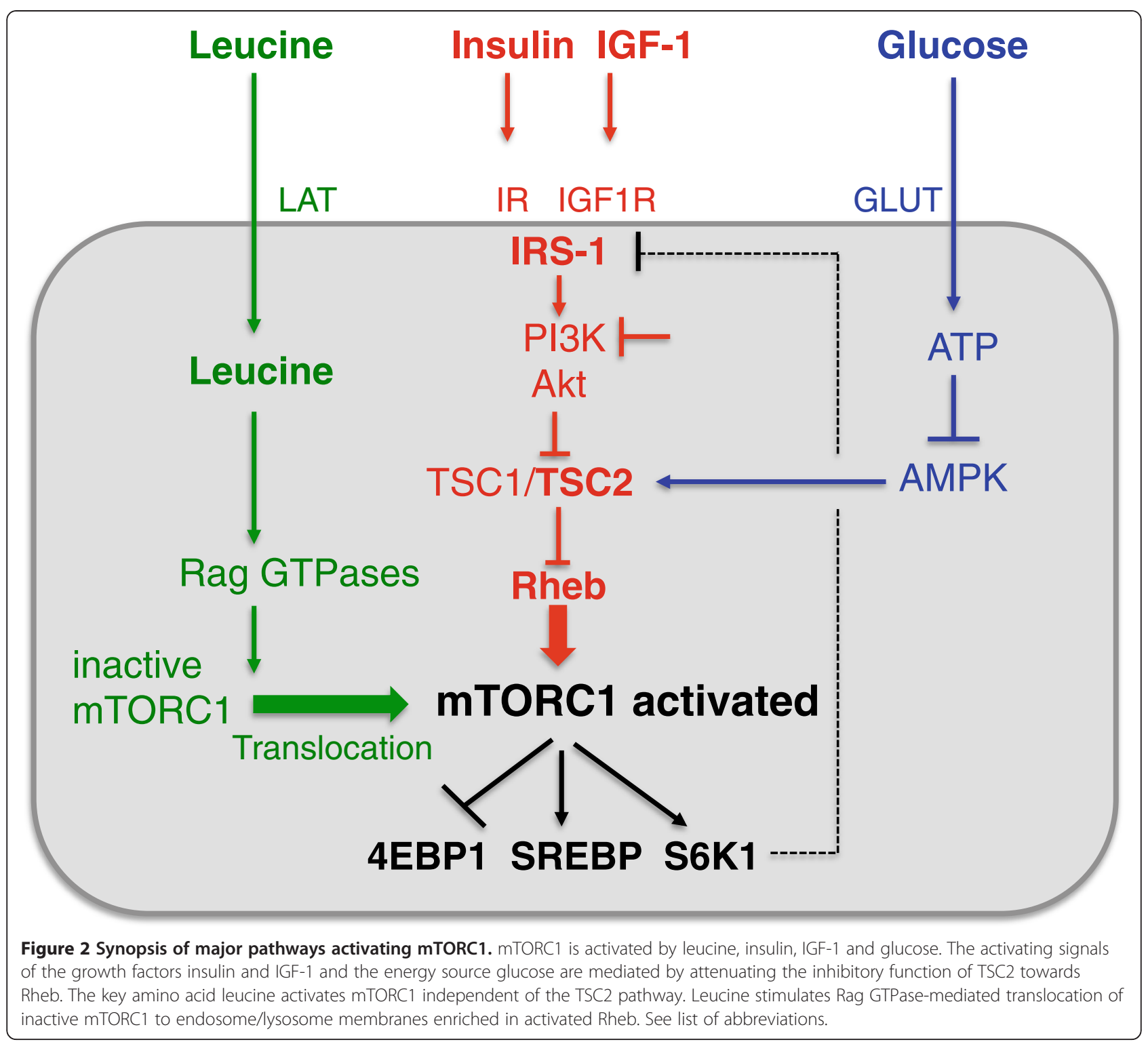

heterodimeric complex. TSC1 stabilizes TSC2 that possesses a GTPase-activating protein, which hydrolyses GTP to GDP. The TSC1/TSC2 complex provides this function to Rheb leading to inactivation of Rheb. In contrast, insulin and IGF-1, both activate the kinase Akt (protein kinase B) as well as other growth-related kinases such as ERK and RSK, which phosphorylate TSC2 and thereby attenuate the inhibitory function of the TSC1/TSC2 complex. This inhibition leads to activation of Rheb with final activation of mTORC1 [57-60] (Figure 2).

Besides the important input of growth factor signaling on mTORC1 activation, AMPK, an essential energy sensor, plays a key role in energy-dependent mTORC1 regulation. During states of energy-deficient conditions like glucose deprivation, ATP levels fall and AMP levels rise, resulting in AMPK activation. AMPK phosphorylates TSC2 and Raptor, thereby suppressing mTORC1 activity $[60,61]$. Abundant cellular energy provided by hypercaloric and high glycemic loads of Western diet thus reduces AMPK activity and stimulates mTORC1 signaling. In Western diet hyperglycemic food compounds are frequently combined with dairy products like cornflakes with milk or pizza and burgers combined with cheese.

Notably, leucine has been identified as the primarily responsible branched-chain amino acid for mTORC1dependent stimulation of skeletal muscle protein synthesis [52]. In fact, in response to amino acid depletion, mTORC1 activity is rapidly abolished [62]. Amino acid starvation impairs binding of mTORC1 to Rheb [63]. From all essential amino acids, leucine exerts the 
greatest effects on mTORC1 signaling $[42,48,51,62]$. Recent evidence has been provided that amino acids and especially leucine promote the cellular translocation of inactive mTORC1 to lysosomal compartments enriched in activated Rheb [53,55]. This spatial regulation of inactive mTORC1 by amino acids is mediated by an active Rag heterodimer, which is of utmost biological importance for amino acid sensing by mTORC1. Thus, mTORC1 integrates not only growth factor and energy derived signals towards Rheb, but requires a parallel signal input of leucine for final mTORC1 activation by translocation of inactive mTORC1 to cell compartments enriched in activated Rheb (Figure 2). These two independent major pathways of mTORC1 activation explain why either insulin and IGF-1 signaling or amino acid signaling alone is not sufficient to reach maximal mTORC1 activation. Insulin is not able to activate the mTORC1 pathway when cells are deprived of amino acids [64]. Indeed, both insulin- and amino acid signaling are required for maximal mTORC1 activity [65]. Evidence will be provided that only milk proteins in comparison to meat and fish have the unique ability to preferentially increase both the insulin/IGF-1 and the leucine signaling pathways necessary for maximal mTORC1 activation.

Growing cells and especially proliferating tumor cells not only require increased amounts of amino acids and protein but also high amounts of lipids to enlarge their cellular membrane compartments. It is thus not surprising that the key transcription factor of lipid biosynthesis SREBP-1 (sterol regulatory element binding protein-1) is dependent on upstream activation of mTORC1 $[66,67]$.

\section{Oncogenic mTORC1-signaling in prostate cancer cells}

Increased insulin, IGF-1 and especially leucine signaling with activation of mTORC1 are not only a requirement for physiological growth during the neonatal period and puberty but play a pivotal role in the process of tumorigenesis [43,68-74]. In addition to various other cancers, signaling pathways that activate mTORC1 are frequently deregulated in PCa $[43,74,75]$. mTORC1 is upregulated nearly in $100 \%$ of advanced human PCa [76] (Figure 3). Activation of mTORC1 is a central component downstream of the phosphatidyl-inositol-3-kinase (PI3K)/Akt signaling cascade. Akt-mediated phosphorylation of TSC2 prevents TSC1/TSC2 complex formation, which drives the small GTPase Rheb into the GTP-bound active state [77], leading to the phosphorylation and activation of mTORC1 at Ser2448 [78,79]. PTEN, phosphatase and tensin homologue deleted on chromosome 10, is a negative regulator of Akt activation, as it converts phosphatidylinositol 3,4,5-triphosphate $\left[\operatorname{PtdIns}(3,4,5) \mathrm{P}_{3}\right]$ back to $\operatorname{PtdIns}(4,5) \mathrm{P}_{2}$, leading to reduced recruitment of Akt to the cell membrane, which is the important location for PDK-1-mediated final phosphorylation and full activation of Akt [80]. The PI3K/Akt/mTORC1-pathway is aberrantly activated in the majority of PCa due to PTEN copy number loss or loss of function of at least one PTEN allele [75,76,81]. Genetic findings in mouse models implicate mTORC1 hyperactivation in both PCa initiation and progression [82-87]. It has recently been reported that Rheb, the final upstream activator of mTORC1, is amplified in human PCa [88]. In the mouse prostate, Pten haploinsufficiency cooperates with Rheboverexpression and markedly promoted mTORC1mediated prostate tumorigenesis [88] (Figure 3). Compelling evidence has recently demonstrated that mTORC1 controls the translational program of mRNA subsets of genes involved in $\mathrm{PCa}$ initiation, invasion and metastasis [89-91].

\section{Cross-talk between androgen receptor and mTOR in prostate cancer}

The two most frequently activated signaling pathways in $\mathrm{PCa}$ are driven by androgen receptor (AR) and PI3K. Genetic loss of either $m T O R$ or Akt1 is sufficient to signifcantly reduce initiation of $\mathrm{PCa}$ in the conditional Pten mouse model [90-92]. The allosteric mTORC1 inhibitor rapamycin has been shown to revert Akt-dependent early prostate intraepithelial neoplasia (PIN) in young mice through regulation of apoptotic and HIF-1dependent pathways [93]. It has been shown in the prostate-specific Pten-deleted mouse model of PCa that depletion of androgens significantly inhibited tumor growth progression without altering the activation of Akt and mTOR, however, the combination of antiandrogen treatment with rapamycin-mediated mTORC1 inhibition exhibited additive antitumor effects [94]. Recent evidence points to a reciprocal feedback regulation of PI3K and AR singaling in PTEN-deficient PCa [95]. In human and murine tumors with PTEN deletion inhibition of the PI3K pathway promoted AR activity, whereas androgen blockade activated Akt signaling [95]. Combined PI3K and AR inhibition was superior to single agent therapy in PTEN loss PCa [95].

Dihydrotestosterone (DHT)-stimulation of LNCaP prostate cancer cells, which have constitutive PI3K/Akt pathway activation due to loss of PTEN, caused increased expression of cyclin $\mathrm{D}_{1}, \mathrm{D}_{2}$, and $\mathrm{D}_{3}$ proteins, retinoblastoma protein hyperphosphorylation and cell cycle progression [96]. DHT treatment increased mTORC1 activity as assessed by phosphorylation of the downstream targets S6K1 and 4EBP1. However, mTORC1 inhibition with rapamycin blocked the DHTstimulated increase in cyclin D proteins [96]. mTORC1 activation by DHT was dependent on AR-stimulated mRNA synthesis, including genes that regulate cellular leucine availability [96]. L-type amino acid transporters 


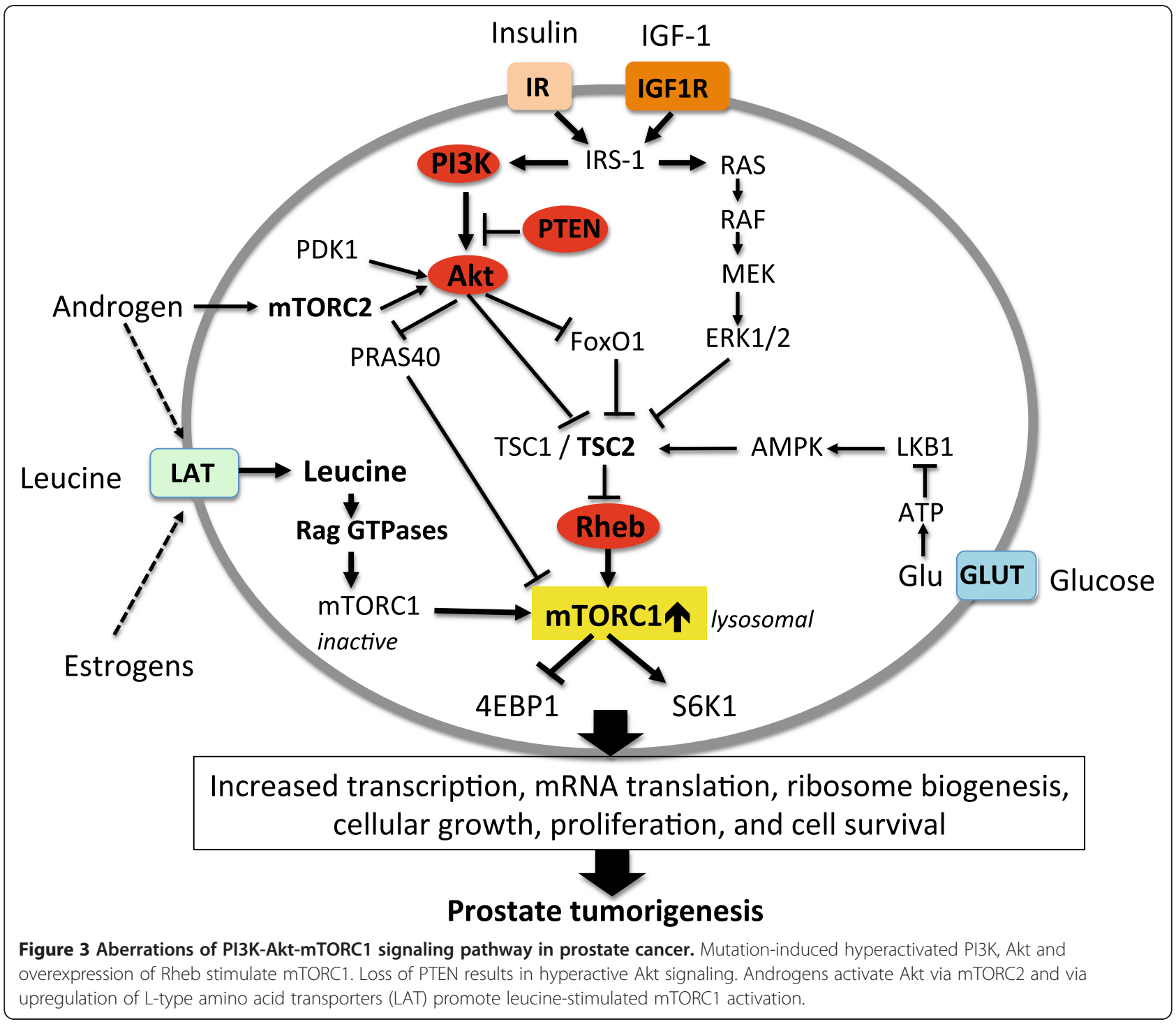

such as LAT1 and LAT3 mediate the uptake of essential amino acids, especially leucine, for leucine-mediated mTORC1 signaling promoting cell growth and proliferation of PCa cells [97]. In the androgen-sensitive LNCaP cell line, androgen-induced upregulation of LAT3 expression was related to increased leucine-mTORC1mediated tumor cell growth [97]. High levels of LAT3 were detected in primary disease, whereas increased levels of LAT1 were observed after ADT and in metastatic lesions [97]. It has recently been shown that BCAA metabolism is affected by malignant progression of PCa cells [98]. Androgens rapidly reduced the protein concentration of the cell cycle inhibitor p27 in PCa cells by increasing proteasome-mediated degradation of p27 [99]. Androgens increased mTORC2-mediated Akt (S473) phosphorylation, which stimulated Akt-mediated phosphorylation of p27(T157), the critical signal for p27 proteasomal degradation [99]. Furthermore, androgen-
mTORC2-mediated activation of Akt resulted in increased phosphorylation of FoxO1, which in its phosphorylated form is extruded from the nucleus into the cytoplasm [99]. Activated Akt is part of the canonical pathway activating mTORC1. Furthermore, cytoplasmic FoxO1 has been shown to bind to the C-terminal sequence of TSC2, thereby disrupting the TSC1/TSC2 complex resulting in further activation of mTORC1 [100]. Moreover, androgen-mediated nuclear FoxO1 extrusion resulted in diminished expression of the AMPK activator Sestrin3, thus allowing further activation of mTORC1 [101].

Recently, Hsieh et al. [91] have demonstrated that complete mTOR inhibition by the ATP site inhibitor of mTOR, INK128, prevented PCa invasion and metastasis in vitro. Obviously, mutations or activating posttranslational modifications of the upstream activators of mTORC1 (Akt, PI3K, Rheb, and loss of PTEN function) 
amplify oncogenic mTORC1 signaling in PCa cells (Figure 3), which drives the 'cancerous' translation machinery steering cancer initiation, cancer invasion and metastasis [91]. Thus, substantial evidence underlines the pivotal role of exaggerated mTORC1 signaling in both PCa development and progression. Continuously increased mTORC1 signaling has been associated with tumor initiation as well as tumor progression [91]. In fact, sustained proliferative signaling has been identified as a hallmark of cancer and comprises the most important biological capability during the multistep development of human tumors [102].

\section{Mammalian milk: an endocrine mTORC1 activating system for neonatal growth}

To understand the impact of dairy protein consumption on PCa tumorigenesis, we have to appreciate the signal transduction of mammalian milk. Although the growthstimulating effect of cow's milk has been recognized since 1928, from it's effect on childhood stature, the growth-promoting pathways of milk-derived signal transduction have not been a matter of medical concern [103]. There is substantial epidemiological evidence that cow's milk consumption increases linear growth and body mass index in infants and accelerates the onset of menarche [104-106]. The function of mammalian milk is not only to provide sufficient calories and nutrients to the newborn but in parallel to promote postnatal growth by milk-mediated growth factor signaling. This overlooked growth-promoting functionality of milk represents the fundamental obstacle, which for many decades obscured the link between the growth-stimulating activity of cow's milk and cow's milk-mediated promotion of cancer growth. To fulfill its biological function to promote growth and survival, milk enhances the activity of mTORC1 by increasing 1) insulin/IGF-1 signaling leading to activation of Rheb, and 2) by providing substantial amounts of the essential BCAAs like leucine, which stimulate amino acid-mediated mTORC1 activation.

\section{Differences in the magnitude of mTORC1 signaling of cow's milk versus human milk}

For adequate species-specific growth requirements, each mammalian species has developed its own species-specific magnitude of milk-mediated mTORC1 signaling. The strength of mTORC1-mediated stimulation of mammalian growth is associated with the total protein and total leucine concentration in mammalian milk [107]. The milk of various mammalian species shows significant speciesdependent variations in the concentration of total milk protein. However, milk of all mammals exhibit a constant ratio of $0,1 \mathrm{~g}$ of leucine per $1 \mathrm{~g}$ of total milk protein [108]. Remarkably, species with the highest milk protein concentration exhibit the most rapid growth rate. An inverse relation exists between the protein plus leucine content of mammalian milk and the neonate's rate of birth weight duplication [107]. For instance, the leucine content of rat's milk is $11 \mathrm{~g} / \mathrm{L}$, of cat's milk $8,9 \mathrm{~g} / \mathrm{L}$, of cow's milk 3,3 g/L, and of human milk $0,9 \mathrm{~g} / \mathrm{L}$, respectively [108]. The rat doubles birth weight already after 4 days, the cat after 10 days, the calf after 40 days, and the human neonate, the mammal with the slowest

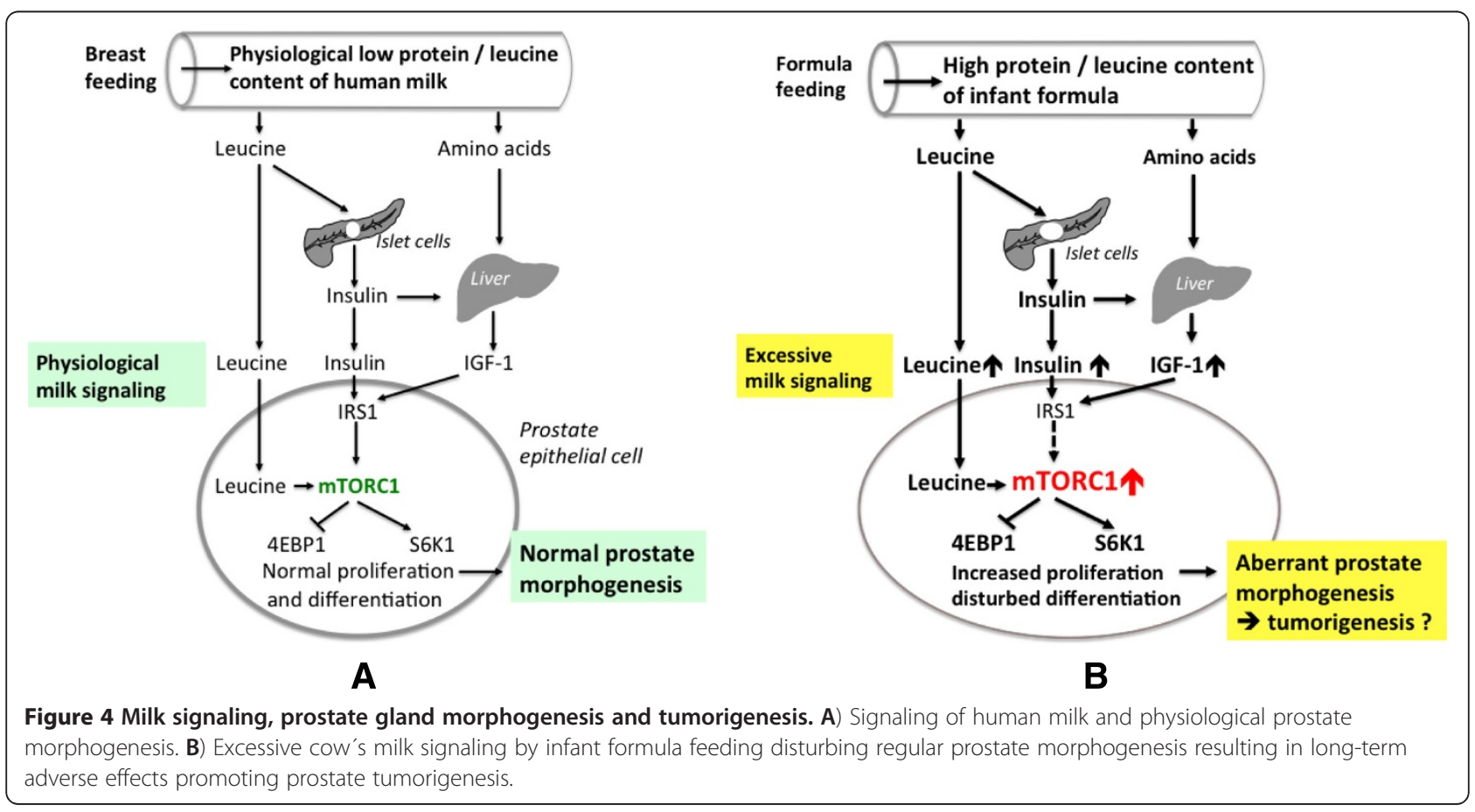


growth rate, after 180 days, respectively [107]. These data imply, that the leucine-mTORC1 signaling axis of cow's milk is much higher than that of human milk, as cow's milk contains threefold the amount of total protein and total leucine in comparison to human milk $[107,108]$. Moreover, the weight gain of calves during the first year of cow's milk feeding $(0.7-0.8 \mathrm{~kg} /$ day $)$ is nearly 40-times higher than that of breast-fed human infants $(0.02 \mathrm{~kg} /$ day $)$ [109]. It has been demonstrated that cow's milk-based infant formula feeding significantly increases serum concentrations of leucine, insulin, and IGF-1 in comparison to physiological breastfeeding [110,111] (Figure 4). Thus, cow's milk-based infant formula feeding induces higher magnitudes of mTORC1 signaling in comparison to natural breastfeeding of human milk $[112,113]$. The great differences in the magnitude of mTORC1 signaling may explain the differences in growth velocity and weight gain between Bos taurus and Homo sapiens. Moreover, the relatively low mTORC1 signaling axis of human neonates in comparison to Bos taurus allows a slower rate of brain growth permitting more time for the accumulation of long-chain omega- 6 polyunsaturated fatty acids (specifically 20:4n6) and long-chain omega-3 polyunsaturated fatty acids (specifically $22: 6 \mathrm{n} 3$ ), critical nutrients for the development of complex brain functions, an evolutionary advantage of Homo sapiens [114]. With regard to mTORC1-dependent postnatal events in prostate morphogenesis and prostate gland development it is of special concern that infant formula feeding in comparison to natural breast-feeding may over-stimulate mTORC1 signaling thereby disturbing physiological conditions of prostate growth and development during the postnatal period.

\section{Cow's milk protein elevates IGF-1 serum levels: a known risk factor of prostate cancer}

Insulin-like growth factor-1 (IGF-1) is an important activator of PI3K/Akt signaling resulting in mTORC1 activation $[57,60,68]$. It has been demonstrated in rat hepatocyte primary cultures that hepatic IGF-1 gene expression directly depends upon the availability of essential amino acids [115]. Elevated IGF-1 serum concentrations are associated with consumption of animal versus vegetable proteins. In comparison to meat protein increased intake of milk protein by milk consumption from 200 to $600 \mathrm{ml}$ resulted in a 30\% increase in IGF-1 serum concentrations [116]. Furthermore, skim milk protein versus meat intake increased serum IGF-1 concentrations in 8-year-old boys [117], underlining the higher IGF-1-enhancing activity of milk proteins in comparison to meat protein. In prepubertal boys, casein versus whey protein elicited a greater rise in plasma IGF-1 concentrations, whereas whey protein versus casein elicited a greater rise in postprandial insulin plasma concentrations [118]. Thus, there is substantial evidence in humans, that cow's milk protein intake in comparison to meat protein exerts stronger effects on proteininduced IGF-1 signaling. Therefore, it is reasonable to differentiate between signaling proteins like milk proteins and structural proteins like meat and fish protein, which are less efficient in elevating insulin and IGF-1 plasma concentrations than milk proteins.

Lower IGF-1 signaling due to mutations with reduced activity of the IGF-1 receptor are associated with longevity and lower incidence rates of cancer [119]. Moreover, congenital IGF-1 deficiency has been shown to confer protection against the development of malignancies in humans including a lower prevalence of PCa [120]. In a cohort of 99 untreated individuals with Laron syndrome, who exhibit growth hormone receptor mutations with congenital IGF-1 deficiency, only one nonlethal malignancy has been detected after 22 years of monitoring, whereas not affected relatives exhibited a cancer prevalence of $17 \%$ with $\mathrm{PCa}$ being the third most common cancer in this control population [121]. Cells cultured with IGF-1-deficient serum of Laron individuals showed a 20\% reduction of TOR expression and exhibited increased activity of nuclear FoxO protein levels [122]. Thus, low IGF-1 serum levels attenuated IGF-1/ mTORC1-mediated cell proliferation and increased FoxO-mediated anti-oxidative responses by upregulation of superoxide dismutase and catalase as well as by FoxO-driven pro-apoptotic responses, all of which are most important cancer-preventive mechanisms [122]. In accordance with observed cancer-protective effects of low IGF-1 signaling is a recent epidemiological study, which demonstrated that high serum IGF-1 concentrations were associated with increased cancer deaths in older men [123]. Notably, men with type 2 diabetes were found to have a lower incidence of $\mathrm{PCa}$, presumably due to decreased IGF-1 serum levels [124]. However, recent large cohort studies have reported the association of type 2 diabetes with advanced high-grade PCa [125]. Data from meta-regression analyses of case control studies have provided substantial evidence that high serum concentrations of insulin and IGF-1 are associated with increased risk of $\mathrm{PCa}$ [126-128]. Increased serum concentrations of IGF-1 are specifically involved in the early pathogenesis of PCa [126]. The European Prospective Investigation into Cancer and Nutrition clearly confirmed the correlation between increased dairy protein consumption and raised IGF-1 serum concentrations in adults $[129,130]$. A recent cross-sectional analysis using data of 1,798 men in the UK demonstrated that for one standard deviation increase in dairy protein intake, IGF-1 increased by $6.02 \mathrm{ng} / \mathrm{ml}$ [131]. Among other animal- and plant-derived proteins, dairy protein was most strongly 
associated with increased IGF-1 serum concentrations [131]. Notably, low versus high meat intake was not associated with a change of IGF-1 serum levels [131]. These data strongly imply, that the increase of serum IGF-1 concentrations by cow's milk protein consumption may result in elevated IGF-1-driven mTORC1 signaling, the driving mechanism promoting the initiation and progression of PCa.

\section{Cow's milk protein intake increases postprandial serum insulin levels}

Insulin, like IGF-1, is a growth hormone, which activates insulin receptor as well as IGF-1 receptor signaling and stimulates the activity of mTORC1 $[68,132]$. As it is the biological function of mammalian milk to promote growth, milk performs its mission by increasing the serum concentrations of both growth hormones insulin and IGF-1. Cow's milk proteins, which are absent in Paleolithic diets and traditional diets of Southeast Asia, significantly contribute to higher insulin/IGF-1 signaling of Western diet [133]. Mammalian milk upregulates insulin secretion of pancreatic $\beta$-cells as well as IGF-1 synthesis by the liver (Figure 4). BCAAs, predominantly leucine, stimulate $\beta$-cell mTORC1 resulting in increased insulin secretion [134-137]. Moreover, milk consumption not only activates the somatotropic axis but also the enteroinsular axis by stimulating intestinal incretin secretion of glucose-dependent insulinotropic polypeptide (GIP), which further augments insulin secretion [138,139]. Milk's excessive insulinotropic activity is well characterized by cow milk's high insulinemic index [140].

It has recently been confirmed that BCAA-enriched postprandial serum after ingestion of whey protein by healthy individuals significantly induced insulin secretion of isolated mouse pancreatic islets [141]. The insulinogenic effect of whey protein was predominantly mediated by the whey protein-derived amino acids leucine, isoleucine, valine, lysine and threonine and was augmented by increased intestinal release of GIP [141]. Casein protein hydrolysate and leucine co-ingestion in patients with type 2 diabetes stimulated postprandial insulin secretion [142]. Notably, increased daily intake of milk but not meat significantly elevated fasting insulin and IGF-1 serum concentrations and increased insulin resistance in 8 -year old boys $[117,143]$. Milk-induced insulin resistance can be well explained by increased mTORC1mediated activation of S6K1. Insulin receptor substrate-1 (IRS-1) is an important target of S6K1 phosphorylation, which inhibits downstream insulin signaling in adipose tissue, liver and skeletal muscle [144] (Figure 2).

In accordance with epidemiological evidence, an association of diet-induced hyper-insulinemia with accelerated growth of $\mathrm{LNCaP}$ xenografts has been reported [145]. Moreover, the insulin-analogues glargine and detemir exhibited IGF-1-like mitogenic and anti-apoptotic activities in cultured $\mathrm{PC}-3$ prostate cancer cells [146]. In contrast, reduced circulating IGF-1 levels obtained by calorie restriction attenuated mTORC1 signaling and inhibited tumorigenesis [147]. Dietary restriction in mice resulted in reduced IGF-1 serum concentrations and decreased mTORC1 activity in the dorsolateral prostate of mice [148]. Recent evidence supports a "higher-level" interaction between AR signaling and IGF-1 signaling via recruitment of direct pathways toward activation, transcriptional regulation, and protein posttranslational changes, all critical to PCa cell survival [149]. The reduction in high protein intake commonly provided by Western diet has been proposed as an important strategy for dietary anti-cancer interventions [150]. However, the quantity and quality of protein intake has been recognized as the key determinant of circulating IGF-1 concentrations and postprandial hyperinsulinemia. Milk (insulinemic index $>100$ ) and especially the whey proteins are highly insulinotropic in comparison to meat (insulinemic index 51) [140]. Moreover, total protein intake is not the most important determinant controlling high IGF-1 serum concentrations as milk protein induces higher IGF-1 concentrations than meat. Thus, for understanding the role of nutrient signaling in cancer biology it appears to be of pivotal importance not only to consider total daily protein intake but rather to differentiate between the intake of BCAA-enriched signaling proteins (derived primarily from milk) and the intake of less insulinotropic structural proteins (primarily derived from meat and fish).

\section{Whey protein ingestion activates $\mathrm{mTORC} 1$ signaling}

There is yet no direct experimental evidence for the activation of mTORC1 in prostate epithelial cells after cow's milk protein consumption. However, it has been convincingly demonstrated that a single dose (26.6 g) of whey protein isolate in young men immediately after a resistance exercise significantly increased mTORC1 signaling in skeletal muscle (vastus lateralis) $2 \mathrm{~h}$ post-exercise [151]. Whey protein intake significantly enhanced the phosphorylation of mTOR(Ser2448), 4EBP1(Thr37/46) and S6K1(Thr389) at $2 \mathrm{~h}$ post-exercise [151]. These data are in agreement with studies in rat skeletal muscle, which have demonstrated a dose-response between leucine ingestion and increased S6K1(Thr389) phosphorylation [152]. In addition to S6K1 phosphorylation, the phosphorylation of 4EBP1 is also sensitive to amino acid provision [153], and the site-specific phosphorylation of Thr37/46 is reported to be crucial for optimal activation of 4EBP1 [154]. These data of whey protein-induced mTORC1 activation in muscle cells are most likely conferrable to other human tissues like the prostate gland and support the role of dairy protein-induced mTORC1 
signaling as a fundamental biological function of mammalian milk to promote growth.

\section{Milk-mediated mTORC1 signaling amplifies oncogenic mTORC1 signaling}

Most importantly, to achieve the physiological requirements for adequate growth, milk proteins provide the highest amounts of leucine and the most effective BCAAs required for mTORC1 activation $[48,51,52,62]$. Whey proteins have to be regarded as unique life starter proteins that contain the highest amount of leucine (14\%), followed by casein (10\%), the major protein constituent of cow's milk and cheese [155]. Since mTORC1 signaling positively regulates protein synthesis and ribosome biogenesis, both of which require amino acids, it makes physiologically sense that mTORC1 signaling is highly dependent upon amino acid availability. Withdrawal of leucine has been shown to be nearly as effective in down-regulation of mTORC1 signaling as withdrawal of all amino acids [52,62]. Moreover, the preeminent effect of leucine withdrawal has been consistently observed in a variety of cell types, thus underlining the primacy of leucine in amino acid-mediated mTORC1 regulation [47-49].

It is important to realize that milk protein intake appears to be more efficient in activating mTORC1 than meat or cheese protein consumption as milk contains the highly water soluble and easily hydrolysable leucinerich whey proteins, which are responsible for the rapid and elevated postprandial rise in plasma leucine concentrations [139,141]. These whey protein-mediated high pulsatile elevations of plasma leucine- and GIP concentrations may explain the high insulinemic index of milk and other whey protein-containing milk products like yoghurt (insulinemic index of 89-115) in comparison to energy-equivalent protein uptakes of beef (insulinemic index of 51) and cheese (insulinemic index of 45) [156]. In comparison to meat, intake of milk and whey proteincomprising milk products thus results in higher and more rapid increases of leucine and insulin signals, which are both important downstream activators of mTORC1. As signal transduction in biological systems is known to respond more efficiently to sudden increases of incoming signals ( $\Delta$ signal) than to prolonged exposures of high signal levels, the pronounced differences in the leucinemTORC1-insulin kinetics between whey protein and meat may explain why Paleolithic type diets are less insulinotropic and presumably less effective in mTORC1 stimulation than whey protein-accentuated Western diets [157]. Previously, the growth-promoting effects of milk consumption was explained exclusively by milk's ability to induce higher plasma concentrations of IGF-1 while ignoring the co-stimulatory effects of leucine, insulin, and IGF-1 signaling, all of which are finally integrated by the central regulator mTORC1 [158]. In this regard, meat and fish protein consumption, in comparison to whey protein-enriched dairy products, may exert less oncogenic stimulation. Circulating pulsatile rises of leucine and insulin concentrations together with permanently elevated serum concentrations of IGF-1 may be responsible for cow milk's optimized mode of hyperactivated mTORC1 signaling, which promotes growth stimulation of prostate epithelial cells and further amplifies already upregulated oncogenic mTORC1 signaling of PCa cells with preexisting alterations of cell growth-promoting signaling pathways (Table 1; Figure 4B).

\section{BCAA and leucine overload by dairy protein-rich Western diet}

A worldwide continuous increase of dairy protein consumption has occurred in Western countries, as exemplified by the annual increase of cheese consumption per capita in the Federal Republic of Germany from $3.9 \mathrm{~kg}$ in 1935 to $23.0 \mathrm{~kg}$ in 2011 (Figure 1) [112]. The high BCAA and leucine content of animal protein-rich Western diet strongly contrasts to the low dietary leucine amounts in traditional Asian diets because of their high reliance upon plant proteins, containing little leucine. Thus, during the last five decades a steady increase in total leucine intake in westernized countries has occurred as exemplified by the German per capita leucine consumption (Table 2). The abundant cheese consumption in Western countries substantially contributed to the increased total leucine intake, which has been recognized as an important activating signal of mTORC1 and may explain the association between cheese consumption and increased risk of PCa [6]. For example, the leucine content of $100 \mathrm{~g}$ of Gouda cheese (2.4 g leucine) is considerably higher than that of $100 \mathrm{~g}$ white cabbage $(0.056 \mathrm{~g})$, or $100 \mathrm{~g}$ apple $(0.016 \mathrm{~g})$. To reach the leucine content provided by $100 \mathrm{~g}$ Gouda cheese, $4.2 \mathrm{~kg}$ of white cabbage or 100 apples would have to be consumed [112]. Cheese is widely consumed with fast food products like pizza, tacos and cheeseburgers. The abundance of leucine in the Western diet and especially the combination of easily releasable leucine from whey proteins in combination with high glycemic load foods may

\section{Table 1 Comparison of leucine-insulin-IGF-1-signaling between dairy-derived signaling proteins versus meat-} derived structural proteins [116-118]

\begin{tabular}{llll}
\hline Protein source & Leucine & Insulin & IGF-1 \\
\hline Whey & $\uparrow \uparrow \uparrow$ & $\uparrow \uparrow \uparrow$ & \\
\hline Casein & $\uparrow \uparrow$ & & $\uparrow \uparrow \uparrow$ \\
\hline Milk protein & $\uparrow \uparrow$ & $\uparrow$ & $\uparrow \uparrow \uparrow$ \\
\hline Meat protein & $\uparrow \uparrow$ & $\uparrow$ & $\uparrow$ \\
\hline
\end{tabular}


Table 2 Annual animal protein-derived per capita leucine intake in Germany

\begin{tabular}{|c|c|c|c|}
\hline Animal protein $[\mathrm{g} / \mathrm{y}]$ & $1950 / 51$ & $1974 / 75$ & $2007 / 08$ \\
\hline Total meat $(\approx 21 \mathrm{~g}$ Leucine/kg) & 552 & 1172 & 1268 \\
\hline Egg/egg products ( $\approx 13 \mathrm{~g}$ Leucine $/ \mathrm{kg})$ & 98 & 225 & 169 \\
\hline Fish ( $\approx 19 \mathrm{~g}$ Leucine/kg) & 131 & 78 & 143 \\
\hline Cheese ( $\approx 25 \mathrm{~g}$ Leucine $/ \mathrm{kg})$ & 96 & 293 & 558 \\
\hline $\begin{array}{l}\text { Average total per capita leucine } \\
\text { uptake }[\mathrm{g} / \mathrm{y}]\end{array}$ & \multicolumn{3}{|c|}{$877(100 \%) 1768$ (199\%)2138 (241\%) } \\
\hline
\end{tabular}

thus promote mTORC1-driven prostate tumorigenesis. The introduction of widespread refrigeration technology since the 1950s in industrialized countries has allowed for the increased and persistent availability of dairy proteins.

\section{Commercial cow's milk: a source of dietary estrogens}

There is recent concern that not only androgens, but also estrogens promote PCa [159]. Commercialized milk production by pregnant cows releases uncontrolled amounts of bovine steroids into the human food chain. PCa cells express estrogen receptors (ERs). ADT has been shown to upregulate stromal ERs [160]. The addition of estradiol $\left(10^{-8} \mathrm{M}\right)$ significantly promoted growth of LNCaP cells in vitro [41]. In industrialized countries, a significant percentage of commercial milk comes from pregnant cows containing elevated concentrations of estrogens and progesterone [161-164], which may synergistically enhance mTORC1 signaling. 5 $\alpha$-Pregnanedione, a steroid compound of commercial cow's milk, is a direct precursor of DHT and may act through mTORC2-Akt as well as ARLAT3-leucine-mediated activation mTORC1 in prostate tumorigenesis (Figure 5). Even more evidence underlines the role of estrogens in prostate tumorigenesis $[165,166]$. Animal and limited human studies suggest that estrogens are involved in prostate carcinogenesis by genotoxic mechanisms [166]. 17 $\beta$-estradiol, which is generated from testosterone by the enzyme aromatase, can be converted to catecholestrogens, which through redox cycling may generate reactive metabolites that can adduct to DNA and potentially lead to mutations [166]. Furthermore, developmental studies of prostate morphogenesis demonstrated a critical time for estrogen action during the development of the prostatic tissue [165]. It has been suggested that estrogen-sensitive cells may remain in the prostate and be more responsive to estrogens later in life or be less responsive to the normal controlling mechanisms of prostatic growth [165]. Dogs as with men are able to develop PCa. Marked prostate hyperplasia has been induced in dogs especially by combined administration of DHT with estrogens $[167,168]$.
In the prostate, ER- $\beta$ is preferentially expressed in epithelial cells but ER- $\alpha$ is found in stromal and basal cells [169]. There is evidence for increased ER staining intensity in malignant prostates [170]. Recently, ER- $\beta$ expression has been detected in PCa cells [171]. Notably, in the human breast cancer MCF-7 cell line, $17 \beta$ estradiol stimulated leucine uptake by increasing the expression of LAT1 [172]. Although no data are yet available on estrogen-mediated leucine uptake in $\mathrm{PCa}$ cells, it is conceivable that commercial milk-derived estrogens may further augment leucine-mTORC1signaling of PCa cells. Remarkably, cow's milk feeding to female rats with chemically dimethylbenz (a) anthracene (DMBA)-induced mammary cancer in comparison to milk-free controls promoted the growth of mammary tumors and doubled the number and volume of tumor cells $[173,174]$. Moreover, commercial cow's milk was found to be uterotrophic in rats [175], which represents more evidence of milk's estrogenic and pro-proliferative activity. Remarkably, $17 \beta$-estradiol stimulated leucine uptake by MCF-7 breast cancer cells, which appear to increase leucine uptake predominately by LAT1 [172]. PCa cells coordinate the expression of L-type amino acid transporters such as LAT1 and LAT3 to maintain sufficient levels of leucine needed for mTORC1 signaling and cell growth [97]. Noteworthy, the mTORC1 inhibitor rapamycin inhibited the proliferation of ERpositive breast cancer cells [176]. These animal studies and one human intervention study [164] strongly suggest that commercial cow's milk (especially if it is derived from pregnant cows) contains estrogen metabolites with significant oral bioavailability. This observation is further supported by evidence showing that the most prevalent form of estrogen in cow's milk is estrone sulfate [159], which coincidentally comprises almost half of the conjugated estrogens in the most frequently prescribed oral hormone replacement therapies for menopausal women.

It should be realized that low fat (skim milk) was as effective in mammary tumor promotion as whole milk $[173,174]$. Although it is well known that the lipid soluble steroids of milk are mainly distributed within milk's fat fraction, conjugated estrogens have been found in high amounts in skim milk [162]. In fact, several studies emphasized a stronger association of $\mathrm{PCa}$ with the consumption of low fat/nonfat milk than with whole milk $[16,18,19]$. Hence, it is conceivable that the protein fraction of milk may act synergistically with conjugated estrogens present in commercial skim milk in the promotion of prostate tumorigenesis.

Moreover, Ganmaa et al. [6] provided evidence that the combination of "milk + cheese" was associated with increased risk of $\mathrm{PCa}$ mortality, a combination that is 


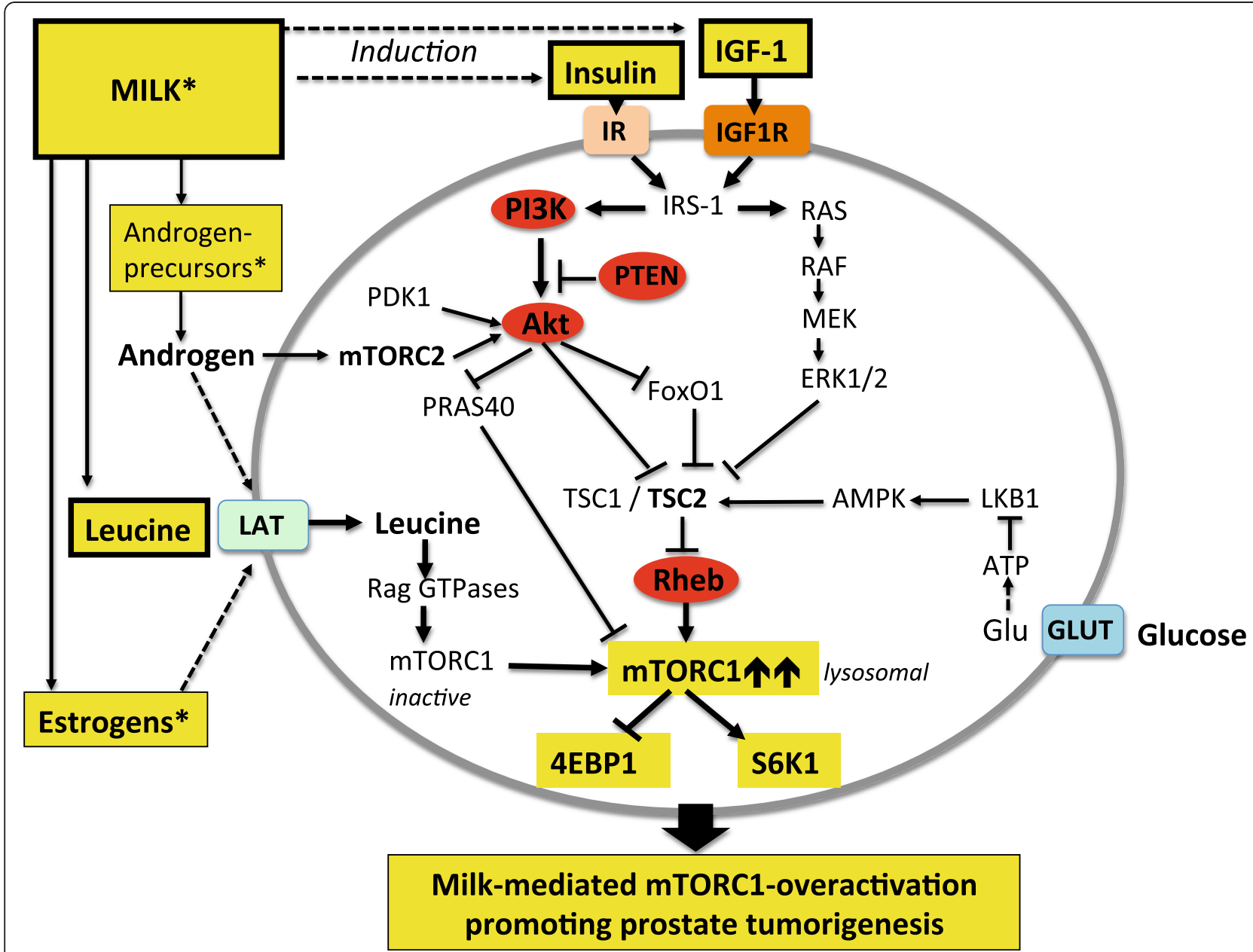

Figure 5 Boostering effects of cow's milk consumption on prostate cancer-associated high mTORC1 signaling. Milk and dairy protein consumption increase serum insulin and IGF-1 concentrations and provide abundant leucine for mTORC1 activation. Milk-derived estrogens and androgen-precursors from pregnant* cows augment LAT-mediated leucine uptake promoting further mTORC1 activation. Milk signaling shares common pathways of PCa with hyperactivated mTORC1 signaling due to cancer-associated alterations of Akt, PI3K, PTEN and Rheb (labeled in red).

subsumed as "total dairy" in various studies [10]. Cheese consumption is a major dietary source of milk fat, which is contaminated by pregnancy-derived bovine estrogen metabolites in free and conjugated forms $[161,162]$. Excessive cheese consumption derived from commercial milk of pregnant cows thus provides an undesirable estrogen load, which may synergistically amplify the intrinsic growth promoting effects of milk proteins. Hence, substantial evidence supports the view that milk signaling shares synergistic effects with oncogenic mTORC1 signaling pathways of PCa. Commercial milk intake by increasing plasma concentrations of insulin, IGF-1, leucine, estrogens and androgen-precursors may amplify preexistent high mTORC1 signaling due to genetic alterations of the PI3K/PTEN/Akt/Rheb/mTORC1 pathway of PCa cells (Figure 5).
Obesity, insulin resistance and increased mTORC-1 signaling and prostate cancer Increased cow's milk signaling via insulin, IGF-1 and leucine has recently been linked to dysregulated early metabolic programming and early promotion of mTORC1-mediated adipogenesis [112,113]. More evidence supports the influence of diet and obesity on prostate health [177]. However, only an overall weak association of $\mathrm{PCa}$ risk with obesity has been reported $[178,179]$. Nevertheless, obesity appears to be associated with more advanced, higher-grade disease and PCa mortality [179-181]. Indeed, a relationship between BMI and advanced PCa has been established [181,182]. Higher milk consumption in children has been associated with increased BMI [105]. It has been recognized that leucine mediates mTORC1 signaling of adipocytes and plays a crucial role in adipogenesis, adipogenic action of PPAR $\gamma$ 
and SREBP-1-mediated lipid synthesis [112,113,183189]. Moreover, leucine-stimulated mTORC1-S6K1 signaling has been shown to play an important role in the induction of insulin resistance [144,190] (Figure 2). In humans, insulin resistance was induced by infusion of high concentrations of amino acids, whereas the mTORC1 inhibitor rapamycin improved insulin action [191]. Infusion of an amino acid mixture to healthy men resulted in elevation of plasma amino acids, hyperinsulinemia and marked activation of S6K1 with increased inhibitory IRS-1 phosphorylation [192] (Figure 2). In comparison to normal subjects, oral doses of leucine $(0,2 \mathrm{~g} / \mathrm{kg})$ stimulated exaggerated insulin release and induced basal hyperinsulinemia in obese patients [193].

Notably, milk consumption in prepubertal boys has been shown to increase serum insulin concentrations associated with the induction of insulin resistance [143]. The resulting hyperleucinemia and hyperinsulinemia may exert leucine- and insulin-mediated stimulatory effects of prostate mTORC1 signaling. In fact, insulin as well as hyperinsulinemic rat serum after generation of high fat diet-induced insulin resistance promoted growth of androgen-independent prostate cancer PC-3 cells [194]. Furthermore, obesity-related higher concentrations of circulating estrogens in synergy with commercial milk-derived estrogens may stimulate leucine uptake of prostate cells thus orchestrating a pro-proliferative metabolic environment enhancing mTORC1 signaling. Moreover, obesity-induced insulin resistance is not only a proliferative risk constellation mediated by hyperinsulinemia but is also associated with elevations in BCAAs including leucine $[195,196]$. In obesity, adipose tissue down-regulates BCAA uptake and metabolism resulting in elevated concentrations of circulating BCAAs $[197,198]$. In obesity and states of insulin resistance, elevated BCAA have been associated with reduced expression of two adipose tissue BCAA catalytic enzymes: mitochondrial branched-chain aminotransferase 2 (BCAT2) and branched-chain $\alpha$-keto acid dehydrogenase (BCKD E1 $\alpha$ subunit) complex [197-199]. Thus, high milk and dairy protein consumption in obese men may have additive effects on already elevated obesity-derived leucine levels, which may further enhance mTORC1 activity of prostate epithelial cells and PCa cells.

\section{Androgen deprivation therapy down-regulates LAT3-mediated leucine uptake}

PCa cells coordinate the expression of cellular amino acid transporters LAT1 and LAT3 to maintain sufficient levels of leucine required for $\mathrm{mTORC} 1$ signaling and cell growth [97]. ADT downregulates AR-mediated expression of LAT3, which is important to maintain intracellular leucine levels for mTORC1 activation. Low levels of intracellular leucine activate the translation of the transcription factor ATF4, which initiates the transcription of LAT1 to restore leucine-mediated mTORC1 signaling [97]. Inhibition of either LAT3 or LAT1 can lead to decreased growth of PCa cells [97]. Thus, it is conceivable, that the total dietary leucine influx as wells as androgen- and estrogen-regulated intracellular leucineuptake mechanisms play important roles for the regulation of leucine-mediated mTORC1 signaling. These findings suggest that preliminary therapeutic responses to ADT may be related to attenuation of androgendependent leucine-mediated activation of mTORC1 [97], a therapeutic mechanism, which may be counterbalanced by high intake of commercial cow's milk protein.

\section{Leucine and mTORC1-dependent inhibition of autophagy}

Autophagy is an evolutionarily conserved catabolic pathway that has multiple roles in carcinogenesis and cancer therapy [200]. Autophagy can inhibit the initiation of tumorigenesis through limiting cytoplasmic damage, genomic instability and inflammation. Loss of certain autophagic genes can lead to cancer [200]. Autophagy is connected to major cancer networks and is predominately regulated by the activity of the mTORC1 pathway [200]. Pathway enrichment analyses recently revealed that mTORC1 and insulin signaling pathways are important in the regulation of genes involved in autophagy [201]. Aberrant autophagy has been implicated to play a major role in tumorigenesis [202,203]. Activated mTORC1 stimulates cell growth and cell proliferation, whereas suppression of mTORC1 activates autophagy [204]. Autophagy is an important catabolic process involving lysosomal turnover of proteins and organelles for maintenance of cellular homeostasis and mitigation of metabolic stress. Autophagy defects are linked to aging and cancer. Autophagy is often impaired in human $\mathrm{PCa}$ due to either activation of the PI3K/Akt/mTORC1 pathway, which inhibits autophagy, or through allelic loss of the essential autophagy gene beclin 1 [205-207]. ADT induces apoptosis, as well as autophagy in androgen-responsive PCa cells [208]. Amino acids and leucine in particular are involved in the regulation of autophagosome formation [209]. Emerging evidence has linked leucine deprivation-induced protein breakdown to autophagy. It has recently been shown, that leucine inhibits autophagy in an mTORC1-dependent manner [210]. It is conceivable that a high dietary influx of leucine may adversely affect autophagy regulation in prostate epithelial cells. Impaired autophagy regulation of prostate epithelial cells and PCa cells by high dairy protein consumption may thus further promote tumorigenesis and may augment aggressive transformation of $\mathrm{PCa}$ cells, especially in those PCa cells exhibiting an allelic loss of beclin-1. It has been shown that mTORC1 inhibition by rapamycin induced autophagy and radiosensitized PTEN null PCa 
cells [211]. Furthermore, the red yeast rice-derived compound monascuspiloin in combination with ionizing radiation has been shown to induce autophagy in PC-3 cells by inhibition of Akt/mTORC1 signaling [212]. In contrast, milk-stimulated anabolic and pro-survival mTORC1 signaling impairs the appropiate mTORC1 balance for maintaining sufficient autophagy and may attenuate autophagy-inducing therapeutic strategies to kill tumor cells. A persistent impairment of the appropriate autophagy balance by continued cow's milk-activated mTORC1 signaling may thus contribute to the initiation of tumorigenesis because reduced autophagy leads to deficient clearance of cells with acquired DNA damage and genetic instability [200]. In this regard, persistent cow's milk consumption with accelerated mTORC1 signaling may not only contribute to the progression of already established tumor cells but may promote the initiation steps of prostate tumorigenesis.

\section{Glucocorticoids inhibit mTORC1 signaling and promote autophagy and tissue atrophy}

It has been demonstrated that dexamethasone treatment decreased epithelial cell proliferation of the rat ventral prostate and reduced mTOR signaling [213]. Recently, the molecular crosstalk between glucocorticoid receptor (GR) and mTORC1 signaling has been elaborated [214]. A well known adverse effect of prolonged systemic glucocorticoid treatment is tissue atrophy, the result of increased cellular autophagy. In skeletal muscle, direct target genes of GR signaling involve the protein REDD1 (regulated in development and DNA damage responses) and the transcription factor KLF15 (Krüppel-like factor-15). Both inhibit mTORC1 activity, although via distinct mechanisms. The REDD1 gene is activated at the promoter level by ligand-bound GR and is transcriptionally induced under stress conditions like hypoxia (via HIF1 $\alpha$ ), which appears necessary for the downregulation of mTORC1 signaling during stress conditions [215]. REDD1 functions upstream of TSC2 and Rheb in order to downregulate mTORC1 signaling in response to glucocorticosteroids [215-217].

KLF15 upregulates gene expression of BCAT2, a mitochondrial enzyme, catalyzing the first step in the catabolism of BCAAs to accelerate BCAA degradation [218]. The glucocorticoid-driven GR-KLF15-BCAT2 axis may negatively modulate the intracellular availability of BCAAs resulting in a negative impact on mTORC1 function in skeletal muscle. Glucocorticoidmediated downregulation of mTORC1 is not only a superb explanation for glucocorticoid-induced muscle atrophy, but also for the observed inhibitory effects on epithelial cell proliferation of the prostate of glucocorticoid-treated rats [213].

\section{Metformin antagonizes leucine-mediated mTORC1 signaling}

Recent evidence points to cancer preventive and antineoplastic activities of the anti-diabetic drug metformin in PCa [219]. Currie et al. [220] reported that PCa mortality, which is increased in patients with type 2 diabetes, was reduced by metformin monotherapy in comparison to monotherapy with sulfonylureas or insulin. Metformin has been associated with improved overall survival of diabetic PCa patients [221]. Available data support the potential dual benefit of metformin on ADT-induced metabolic syndrome and its antineoplastic activity in PCa [222]. Metformin induced an up to 50\% decrease in cell viability in human PCa cell lines (DU145, PC-3, and LNCaP) compared with only a modest effect $(20 \%$ decrease) in P69 cells, a normal prostate epithelial cell line, indicating that metformin may specifically target the proliferation of PCa cells over normal cells [222]. Metformin-induced cell cycle inhibition was accompanied by a strong decrease of the level of cyclin $D_{1}$ and an increase in p27 protein expression, which is typically observed by inhibition of mTORC1 $[46,96,222]$. In contrast, AR stimulation by DHT in LNCaP cells caused increased expression of cyclin $\mathrm{D}_{1}, \mathrm{D}_{2}$ and $\mathrm{D}_{3}$ and stimulated cell cycle progression [96]. Metformin inhibits mitochondrial respiratory chain complex I, which reduces ATP production, and thereby activates LKB1 and AMPK [223]. AMPK inhibits mTORC1 by direct phosphorylation of TSC2 and Raptor [57,60,224] (Figure 5). It has been demonstrated that metformin in combination with the glucose antagonist 2-deoxyglucose induced AMPK-dependent apoptosis of PCa cells [225].

Recently, a further inhibitory mode of metformin action on mTORC1 activity has been demonstrated, which interferes with leucine signaling. Metformin and phenformin have been shown to inhibit amino aciddependent Rag GTPase-mediated mTORC1 activation [226]. Metformin disturbed leucine-dependent Rag GTPases required for translocation of inactive mTORC1 to activated Rheb enriched in lysosomal membranes, thereby reducing mTORC1 activity $[53,55,227]$. Similar to the effect of amino acid withdrawal, treatment of cells growing in amino acid-rich media in the presence of phenformin caused mTORC1 to leave the perinuclear intracellular compartment and to disperse throughout the cytoplasm without affecting amino acid steady state levels. It is thus conceivable that the biguanide metformin $\left(\mathrm{C}_{4} \mathrm{H}_{11} \mathrm{~N}_{5}\right.$; molar mass 129.1) functions as a competitive inhibitor of leucine $\left(\mathrm{C}_{6} \mathrm{H}_{13} \mathrm{NO}_{2}\right.$; molar mass 131.2) in the Rag GTPase-dependent process of mTORC1 activation. Notably, the daily dose of metfor$\min (2 \mathrm{~g} /$ day $)$ is in the range of leucine intake derived from daily consumption of $100 \mathrm{~g}$ meat or cheese. Thus, disruption of leucine-mediated mTORC1-signaling by 
metformin may explain metformin's antineoplastic activity in PCa. Moreover, the combination of metformin treatment of patients receiving ADT would potentiate the treatment effect on mTORC1 signaling as ADT reduces intracellular leucine uptake, while metformin suppresses leucine-mediated translocation of inactive mTORC1 to lysosomal compartments enriched in activated Rheb.

\section{Decreased leucine uptake and attenuated mTORC1 signaling by plant-based diets}

The balance of a plant-based as opposed to dairy and animal protein-enriched diet has been appreciated as an important factor for the prevention of $\mathrm{PCa}$ [228]. Evidence has been provided that a diet emphasizing plant over animal product intake has been associated with decreased risk and less aggressive course for PCa [229]. On the other hand, the intake of dairy products and red meat has been associated with increased risk, while the intake of vegetables, especially cruciferous vegetables and tomato products, was associated with a decreased risk of PCa. [230-233]. The potential PCa-protective effect of a plant-based diet may be explained by the reduction of dairy- and animal meat-derived leucine intake, and especially lower insulin and IGF-1 signaling of non-dairy plant-based diets attenuating overall mTORC1 activity. Moreover, diets emphasizing plants, especially cruciferous vegetables, not only decrease leucinedependent mTORC1 activation but they provide natural plant-derived inhibitors of mTORC1.

\section{Natural plant-derived mTORC1 inhibitors}

mTORC1 activation by leucine-rich dairy consumption may be attenuated by natural plant-derived inhibitors of mTORC1. Increasing studies have demonstrated that 3,3'-diindolylmethane (DIM), epigallocatechin gallate (EGCG), genistein, curcumin, resveratrol and caffeine, all inhibit mTORC1 signaling directly or indirectly and have been suggested to reduce the risk of $\mathrm{PCa}$ and other common cancers [234-251].

Especially, the consumption of cruciferous vegetables has been associated with a decreased risk of $\mathrm{PCa}$ [244,245,250]. 3,3'-Diindolylmethane (DIM) is generated in the acidic environment of the stomach following dimerization of indole-3-carbinol monomers present in cruciferous vegetables such as broccoli, brussel sprouts, cauliflower and cabbage. DIM suppresses signaling through Akt/mTORC1 pathways resulting in cell cycle arrest [250]. Recent studies have shown that PDGF-D and its cognate receptor PDGFR- $\beta$ are expressed in prostate tumor tissues, suggesting that PDGF-D might play an important role in the development and progression of PCa. Overexpression of PDGF-D in PC-3 cells resulted in rapid growth and enhanced cell invasion that was associated with activation of mTORC1 [245]. BDIM significantly inhibited both mTORC1 and Akt in PC-3 PDGF-D cells associated with decreased cell proliferation and less invasion [245].

Laboratory and clinical studies have demonstrated that green tea components, specifically the green tea catechin epigallocatechin gallate (EGCG), can induce apoptosis, suppress progression, and inhibit invasion and metastasis of PCa [251]. There is substantial animal and in vitro evidence supporting the chemopreventive effects of green tea polyphenols in PCa $[252,253]$. Tea polyphenols have been detected in prostate tissue in humans after green tea consumption [254]. Intriguingly, EGCG has been proven to function as an ATP-competitive inhibitor of both PI3K and mTORC1 catalytic units [241].

In LNCaP prostate cancer cells, the naturally occurring phytopolyphenol compound resveratrol inhibited the phosphorylation of PI3K, Akt and mTORC1 and induced growth arrest and apoptosis through mTORC1 inhibition and activation of FoxO transcription factors [255].

Thus, accumulating evidence from studies of plantderived mTORC1 inhibitors implies that a higher consumption of vegetables, predominantly cruciferous vegetables in association with green tea consumption may antagonize increased mTORC1 signaling induced by high consumption of dairy proteins. Diets emphasizing vegetables and fruits and restricting dairy products, isolated sugars and cereal grains (which typically have high glycemic loads), like Paleolithic type diets, are associated with reduced insulin and IGF-1-signaling and higher intake of plant-derived mTORC1 inhibitors. It is likely that plants have evolved various natural mTORC1 inhibitors to defend invading opportunistic organisms by attenuating their TOR-dependent growth and metabolic activity.

\section{Dairy protein consumption during critical growth phases of the prostate gland}

At least three major mTORC1-dependent growth phases exist in humans, which affect the growth and development of the prostate gland as well: fetal and postnatal growth of the prostate and sexual maturation of the prostate during puberty. The Danish National Birth Cohort from 50,117 mother-infant pairs provided evidence that increased total daily dairy protein consumption during pregnancy increased the neonate's size at birth and was linearly correlated with increased birth weight [256]. Dairy protein-activated mTORC1 signaling may increase placental growth, which augments the transfer of glucose and amino acids to the fetus thus promoting fetal growth $[257,258]$. It is conceivable that increased dairy protein intake during pregnancy not only stimulates general growth and size of the fetus but may also affect the growth of the prostate during fetal development. 
Prostatic branching morphogenesis is an intricate event requiring precise temporal and spatial integration of numerous hormonal and growth factor-regulated inputs. Gosh et al. recently demonstrated that PI3K/ mTOR activity is robustly induced by androgen during murine prostatic development and showed that PI3K/ mTOR signaling is necessary for prostatic epithelial bud invasion of surrounding mesenchyme [259]. These data point to an important role for $\mathrm{PI} 3 \mathrm{~K} / \mathrm{mTOR}$ signaling in prostatic epithelial invasion and migration and implicate the maintenance of a fine tuned balance of PI3K-mTOR activity as a most critical regulatory circuit for prostatic epithelial morphogenesis [259]. It has been suggested that some of the same signaling pathways may be required for both prostatic morphogenesis and prostate tumorigenesis. Organ morphogenesis is not completed after birth and final organ maturation exceeds into the postnatal feeding period.

It is thus of serious concern that currently available cow's milk-based infant formula provides excessive leucine per feeding content in comparison to the physiological leucine content of human breast milk [100-113]. Serum leucine, total IGF-1 as well as insulin serum concentrations are significantly higher in formula-fed infants compared to breast-fed infants [113]. Median serum concentrations of leucine at 6 months of age were lowest in breast-fed infants $(106 \mu \mathrm{mol} / \mathrm{L})$ compared to infants either fed low-protein formula $(120 \mu \mathrm{mol} / \mathrm{L})$ or high protein formula $(165 \mu \mathrm{mol} / \mathrm{L})$ [113]. Thus, cow's milkderived infant formula does not meet the physiological lower leucine signaling axis required for adequate mTORC1 regulation of the human newborn. These postnatal aberrations of leucine-mediated mTORC1 signaling may have an adverse effect on mTORC1-mediated postnatal prostate morphogenesis, thereby priming metabolic deviations that ultimately promote prostate tumorigenesis.

Not only the perinatal growth phase but also pubertydependent growth and sexual maturation of the prostate requires appropriate signaling to maintain adequate mTORC1-activity during this sensitive period of sexual gland differentiation. In fact, recent epidemiological evidence supports the view that high intake of milk during puberty increased the risk of advanced PCa in adult life, thus questioning the attitude of promoting school milk consumption during puberty and adolescence [30].

\section{Targeted therapy for prostate cancer by inhibition of the PI3K/Akt/mTOR pathway}

Leucine stimulation alone is sufficient to stimulate mTORC1 signal transduction [54]. Activation of mTORC1/ S6K1 signaling is widespread in a number of human cancers [260]. Currently, oncology pays special attention to the prominent role of the activated PI3K/Akt/mTOR pathway in PCa, which has led to the development of multiple new drugs for targeted therapy of PCa [261-264]. Molecular changes in the PI3K/Akt/mTOR signaling pathway have been demonstrated to differentiate benign from malignant prostatic epithelium and are associated with increasing tumor stage, grade, and risk of recurrence [261-264]. AR transcriptional activity as well as AR expression is regulated by Akt [265]. In addition, androgens regulate the Akt pathway by both genomic and non-genomic effects [265]. At this stage, several inhibitors of the mTOR pathway are being assessed in laboratory and clinical trials underlining the pivotal role of aberrant mTOR signaling in PCa tumorigenesis [263]. It has recently been demonstrated that the ATP site mTOR inhibitor INK128 inhibited PCa progression in mice by inhibiting oncogenic mTORC1 signaling [91].

Pharmacological mTORC1 inhibitors thus counteract BCAA, insulin and IGF-1-induced overstimulation of mTORC1 signaling stimulated by the consumption of dairy protein-enriched Western diet.

\section{Conclusion}

Routine cow's milk consumption of another species` milk is an evolutionary novel dietary behavior that has the potential to alter human life history parameters and may have long-term adverse health effects [109]. Historically, the advantage of cow's milk consumption has been associated with reduced infant mortality, improved fertility, increased BMI in children, earlier onset of menarche and increased linear growth during adolescence $[105,106,109]$. However, these at first glance "beneficial" effects may become adverse effects later in life, especially in Western populations with a higher life expectancy. The clinical manifestation of $\mathrm{PCa}$ is a disease of the elderly. However, the initiation phase of $\mathrm{PCa}$ may begin as early as fetal growth.

Our understanding of mammalian milk has changed from a "simple food" to a species-specific endocrine signaling system. Milk's functionality depends on its stimulation of the nutrient-sensitive kinase mTORC1, the critical hub regulating cell growth, proliferation, autophagy and metabolic programming. Increased cow's milk and dairy protein consumption during pregnancy, the period of postnatal infant formula feeding and milk/dairy protein consumption in childhood, adolescence as well as adulthood may promote and maintain abnormally high mTORC1 signaling modifying physiological signaling and mRNA patterns required for adequate tissue morphogenesis and programming resulting in long-term adverse effects on prostate health. Dairy protein-derived activation of mTORC1 signaling may disturb most sensitive "windows" of mTORC1-dependent metabolic programming and autophagy regulation thereby upsetting developmental programming and regular differentiation 
steps of the prostate gland (Figure 4B). This line of thought may explain the observed cancer-protective effect of prolonged breast-feeding, which ensures the physiological mTORC1-signaling axis provided by human milk. Increased mTORC1-signaling due to cow's milk consumption during puberty may explain the association between frequent cow's milk consumption during adolescence and higher risk of aggressive $\mathrm{PCa}$ in adulthood [30,266].

Sufficient evidence has accumulated to justify the rejection of the "high dairy calcium -low vitamin D-hypothesis" of PCa [38], whereas the intrinsic signaling capability of milk proteins along with orally bioavailable estrogen metabolites present in milk from pregnant cows represents a more likely explanation for the role of dairy consumption in the development and progression of $\mathrm{PCa}$ in Western countries $[6,10,42]$. As mTORC1mediated cow's milk signaling shares the same downstream pathways as oncogenic mTORC1 signaling of prostate epithelial cells with growth-promoting genetic aberrations, increased intake of cow's milk and dairy proteins may exaggerate already increased mTORC1 signaling of PCa cells. Thus, cow's milk is not a simple nutrient but an endocrinological effector that provides a pro-survival and anti-autophagy tissue environment promoting the initiation and progression of PCa (Figure 5). In contrast, plant-based dietary regimens are associated with reduced intake of insulinotropic and IGF-1 elevating amino acids as well as cow's milk-derived estrogens and in contrast increase the uptake of potential cancerpreventive natural mTORC1 inhibitors. Hormonal ablation therapy (ADT), metformin treatment, natural mTORC1 inhibitors and targeted therapy with synthetic mTORC1 inhibitors just share a common mode of action: the attenuation of increased mTORC1 activity, which is increased by high milk and dairy protein consumption.

In 1994, Ross and Henderson [267] have asked: "Do diet and androgens alter prostate cancer risk via a common etiologic pathway?" Today, this question may be well explained by androgen- and milk-mediated synergisms in prostate mTORC1 signaling [97]. From an evolutionary perspective it can be concluded that the persistent "abuse" of the growth-promoting signaling system of bovine milk by humans over their entire life span maintains the most important hallmark of cancer biology, i.e., sustained proliferative signaling [102]. The magnitude of mTORC1 signaling of Western diet appears to be much higher than that of Paleolithic diets [133], which are less insulinotropic, provide lower glycemic load and exclude the intake of cow's milk proteins [268-271]. In the 1930s leaders of pediatrics were convinced that human breast milk is "just food" [272]. According to this simplified misconception of milk's biology no further efforts were undertaken to explore milk's growth-promoting signal transduction pathways, allowing the widespread introduction of cow's milkbased infant formula feeding. Subsequent evidence has clearly demonstrated that cow's milk-based infant formula substantially exceeds the insulin, IGF-1 and leucine serum concentrations of formula-fed infants in comparison to breast-fed infants [110-113]. Daily intakes of $500 \mathrm{ml} \mathrm{cow}$ 's milk for children are still routinely recommended by leading pediatricians [158]. This advice means that one third of daily total protein intake (recommendation $56 \mathrm{~g}$ ) in the age-range for 14-18 yearold boys will be administered in form of growth-promoting signaling proteins and not by structural proteins like meat or fish. Because adolescence represents a most critical mTORC1-dependent period of prostate differentiation and the subsequent increased risk for PCa [30], the medical community urgently needs to re-evaluate dietary milk recommendations. Dietary recommendations for children and adolescents require nutrient intakes, which allow an adequate and undisturbed period for prostate morphogenesis and sexual maturation of the prostate gland. In this context, it is of serious concern, that increasing numbers of adolescents and young men consume 60 to $80 \mathrm{~g}$ of highly insulinotropic whey protein concentrates daily to gain muscle mass [273]. Thus, future dietary studies should clarify the impact of increased cow's milk protein intake upon early steps of prostate morphogenesis and differentiation. It will become important in future experimental work to define safe upper limits for long-term milk and dairy intake for the prevention of the most common dairy-promoted cancer in men.

\section{Abbreviations}

ADT: Androgen deprivation therapy; Akt: Akt kinase (protein kinase B, PKB); AMP: Adenosine monophosphate; AMPK: AMP-activated protein kinase; AMP: Adenosine monophosphate; AR: Androgen receptor; ATF4: Activating transcription factor 4; ATP: Adenosine triphosphate; BCAAs: Branched-chain essential amino acids (leucine, isoleucine, valine); BCAT2: Branched-chain aminotransferase 2; 1,25(OH) 2 D: 1,25-Dihydroxyvitamin D; DIM: 3,3'Diindolylmethane; DMBA: Dimethylbenz(a)anthracene; DHT: Dihydrotestosterone; ERK: Extracellular regulated MAP kinase; 4EBP1: Eukaryotic initiation factor (elF) 4E-binding protein 1; EGCG: Epigallocatechin gallate; ER: Estrogen receptor; FoxO: Forkhead box class $O$ transcription factor; GAP: GTPase activating protein; GDT: Guanosine diphosphate; GIP: Glucosedependent insulinotropic polypeptide; GLUT: Glucose transporter protein; GTP: Guanosine triphosphate; IGF-1: Insulin-like growth factor 1; IGF1R: IGF-1 receptor; IR: Insulin receptor; IRS-1: Insulin receptor substrate 1; LAT: L-type amino acid transporter; LKB1: Liver kinase B1; MEK: Mitogen-activated protein kinase; mTORC1: Mammalian target of rapamycin complex 1;

mTORC2: Mammalian target of rapamycin complex 2; PCa: Prostate cancer; PDGF: Platelet-derived growth factor; PDGFR: Platelet-derived growth factor receptor; PI3K: Phosphoinositol-3 kinase; PDK-1: Phosphoinositide-dependent kinase 1; PPARy: Peroxisome proliferator-activated receptor gamma; PRAS40: Proline-rich Akt substrate 40; PTEN: Phosphatase and tensin homologue deleted on chromosome 10; Raptor: Regulatory-associated protein of mTOR; Ras: Rat Sarcoma virus oncogene; Rictor: Rapamycininsensitive companion of mTOR; Rheb: Ras homolog enriched in brain; RSK: P90 ribosomal S6 kinase; S6K1: P70 S6 kinase 1; SREBP-1: Sterol 
regulatory element-binding protein-1; TSC1: Tuberous sclerosis complex 1 (hamartin); TSC2: Tuberous sclerosis complex 2 (tuberin).

\section{Competing interests}

BC Melnik, S M John, P Carrera-Bastos, and L Cordain declare that they have no competing interests.

\section{Authors'contributions}

$\mathrm{BCM}$ was responsible for all translational research, data collection and characterization of the signaling pathways of milk proteins and prostate cancer cells. SMJ, PCB, and LC validated all nutrition-related publications on milk and dairy consumption and their validity in relation to increased risk of prostate cancer. BCM has primary responsibility for the final content. All authors revised, discussed and approved the final manuscript.

\section{Author details}

${ }^{1}$ Department of Dermatology, Environmental Medicine and Health Theory, University of Osnabrück, Sedanstrasse 115, Osnabrück D-49090, Germany. ${ }^{2}$ Center for Primary Health Care Research, Lund University, Lund, Sweden. ${ }^{3}$ Department of Health and Exercise Science, Colorado State University, Fort Collins, CO 80523, USA.

Received: 11 May 2012 Accepted: 6 August 2012

Published: 14 August 2012

\section{References}

1. Globocan (2008) Prostate cancer incidence and mortality worldwide in 2008 summary. 2008. http://globocan.oarc.fr/factsheets/cancers/prostate.asp. Accessed 05/2012

2. World Cancer Research Fund/American Institute for Cancer Research (2007) Food, Nutrition, Physical Activity, and the Prevention of Cancer: A Global Perspective. Washington, DC: American Institute for Cancer Research; 2007. http://www.scribd.com/doc/28815788/Food-Nutrition-Physical-Activity-andthe Prevention-of-Cancer-a-Global-Perspective.

3. Sonn GA, Aronson W, Litwin MS: Impact of diet on prostate cancer: a review. Prostate Cancer Prostatic Dis 2005, 8:304-310.

4. Marshall JR: Diet and prostate cancer prevention. World J Urol 2012, 30:157-165

5. Cheung E, Wadhera P, Dorff T, Pinski J: Diet and prostate cancer risk reduction. Expert Rev Anticancer Ther 2008, 8:43-50.

6. Ganmaa D, Li XM, Wang J, Qin LQ, Wang PY, Sato A: Incidence and mortality of testicular and prostatic cancers in relation to world dietary practices. Int J Cancer 2002, 98:262-267.

7. Colli JL, Colli A: International comparisons of prostate cancer mortality rates with dietary practices and sunlight levels. Urol Oncol 2006, 24:194-194.

8. Ganmaa D, Li XM, Qin LQ, Wang PY, Takeda M, Sato A: The experience of Japan as a clue to the etiology of testicular and prostatic cancers. Med Hypotheses 2003, 60:724-730

9. Giovannucci E, Liu Y, Stampfer MJ, Willett WC: A prospective study of calcium intake and incident and fatal prostate cancer. Cancer Epidemiol Biomarkers Prev 2006, 15:203-210.

10. Allen NE, Key TJ, Appleby PN, Travis RC, Roddam AW, Tjønneland A, Johnsen NF, Overvad K, Linseisen J, Rohrmann S, Boeing H, Pischon T, Bueno-de-Mesquita HB, Kiemeney L, Tagliabue G, Palli D, Vineis P, Tumino R, Trichopoulou A, Kassapa C, Trichopoulos D, Ardanaz E, Larrañaga N, Tormo MJ, González CA, Quirós JR, Sánchez MJ, Bingham S, Khaw KT, Manjer J, Berglund G, Stattin P, Hallmans G, Slimani N, Ferrari P, Rinaldi S, Riboli E: Animal foods, protein, calcium and prostate cancer risk: the European Prospective Investigation into Cancer and Nutrition. Br J Cancer 2008, 98:1574-1581.

11. Ahn J, Albanes D, Peters U, Schatzkin A, Lim U, Freedman M, Chatterjee N, Andriole GL, Leitzmann MF, Hayes RB, Prostate, Lung, Colorectal, and Ovarian Trial Project Team: Dairy products, calcium intake, and risk of prostate cancer in the Prostate, Lung, Colorectal, and Ovarian Cancer Screening Trial. Cancer Epidemiol Biomarkers Prev 2007, 16:2623-2630.

12. Heaney RP: Calcium, dairy, and prostate cancer. Br J Cancer 2007, 96(6):1008.

13. Chan JM, Giovannucci E, Andersson SO, Yuen J, Adami HO, Wolk A: Dairy products, calcium, phosphorus, vitamin $\mathrm{D}$, and risk of prostate cancer (Sweden). Cancer Causes Control 1998, 9:559-566.
14. Chan JM, Stampfer MJ, Ma J, Gann PH, Gaziano JM, Giovannucci EL: Dairy products, calcium, and prostate cancer risk in the Physician's Health Study. Am J Clin Nutr 2001, 74:549-554.

15. Tseng M, Breslow RA, Graubard BI, Ziegler RG: Dairy, calcium, and vitamin $D$ intakes and prostate cancer risk in the National Health and Nutrition Examination Epidemiologic Follow-up Study cohort. Am J Clin Nutr 2005, 81:1147-1154.

16. Kesse E, Bertrais S, Astorg P, Jaouen A, Arnault N, Galan P, Hercberg S: Dairy products, calcium and phosphorus intake, and the risk of prostate cancer: results of the French prospective SU.VI.MAX (Supplémentation en Vitamines etMinnéraux Antioxydants) study. Br J Nutr 2006, 95:539-545.

17. Torniainen S, Hedelin M, Autio V, Rasinperä H, Augustsson Bälter K, Kint A, Bellocco R, Wiklund F, Stattin P, Ikonen T, Tammela TL, Schleutker J, Grönberg H, Järvelä l: Lactase persistence, dietary intake of milk, and the risk for prostate cancer in Sweden and Finland. Cancer Epidemiol Biomarkers Prev 2007, 16:956-961.

18. Park SY, Murphy SP, Wilkens LR, Stram DO, Henderson BE, Kolonel LN: Calcium, vitamin $\mathrm{D}$, and dairy product intake and prostate cancer risk. The Multiethnic Cohort Study. Am J Epidemiol 2007, 166:1259-1269.

19. Mitrou PN, Albanes D, Weinstein SJ, Pietinen P, Taylor PR, Virtamo J, Leitzmann MF: A prospective study of dietary calcium, dairy products and prostate cancer risk (Finland). Int J Cancer 2007, 120:2466-2473.

20. Kurahashi N, Inoue M, Iwasaki M, Sasazuki S, Tsugane AS, Japan Public Health Center-Based Prospective Study Group: Dairy product, saturated fatty acid, and calcium intake and prostate cancer in a prospective cohort of Japanese men. Cancer Epidemiol Biomarkers Prev 2008, 17:930-937.

21. Raimondi S, Mabrouk JB, Shatenstein B, Maisonneuve P, Ghadirian P: Diet and prostate cancer risk with specific focus on dairy products and dietary calcium: a case-control study. Prostate 2010, 70:1054-1065.

22. Qin LQ, Xu JY, Wang PY, Kaneko T, Hoshi K, Sato A: Milk consumption is a risk factor for prostatic cancer: meta-analysis of case-control studies. Nutr Cancer 2004, 48:22-27.

23. Gao X, LaValley MP, Tucker KL: Prospective studies of dairy product and calcium intakes and prostate cancer risk: a meta-analysis. J Natl Cancer Inst 2005, 97:1768-1777.

24. Qin $L Q, X u J Y$, Wang PY, Tong J, Hoshi K: Milk consumption is a risk factor for prostate cancer in Western countries: evidence from cohort studies. Asia Pac J Clin Nutr 2007, 16:467-476.

25. Ma RW, Chapman K: A systematic review of the effect of diet in prostate cancer prevention and treatment. J Hum Nutr Diet 2009, 22:187-199.

26. Rodriguez C, McCullough ML, Mondul AM, Jacobs EJ, Fakhrabadi-Shokoohi D, Giovannucci EL, Thun MJ, Calle EE: Calcium, dairy products, and risk of prostate cancer in a prospective cohort of the United States men. Cancer Epidemiol Biomarkers Prev 2003, 12:597-603.

27. Huncharek M, Muscat J, Kupelnick B: Dairy products, dietary calcium and vitamin $D$ intake as risk factors for prostate cancer: a meta-analysis of 26,769 cases from 45 observational studies. Nutr Cancer 2008, 60:421-441.

28. Dewailly E, Mulvad G, Pedersen HS, Hansen JC, Behrendt N, Hansen JP: Inuit are protected against prostate cancer. Cancer Epidemiol Biomarkers Prev 2003, 12:926-927.

29. Snyder OB, Kelly JJ, Lanier AP: Prostate cancer in Alaska native men, 1969-2003. Int J Circumpolar Health 2006, 65:8-17.

30. Torfadottir JE, Steingrimsdottir L, Mucci L, Aspelund T, Kasperzyk JL, Olafsson O, Fall K, Tryggvadottir L, Harris TB, Launer L, Jonsson E, Tulinius H, Stampfer M, Adami HO, Gudnason V, Valdimarsdottir UA: Milk intake in early life and risk of advanced prostate cancer. Am J Epidemiol 2012, 175:144-153.

31. Adebamowo CA, Spiegelman D, Danby FW, Frazier AL, Willett WC, Holmes MD: High school dietary intake and acne. J Am Acad Dermatol 2005, 52:207-211.

32. Adebamowo CA, Spiegelman D, Berkey CS, Danby FW, Rockett HH, Colditz GA, Willett WC, Holmes MD: Milk consumption and acne in adolescent girls. Dermatology Online J 2006, 12:1-12.

33. Adebamowo CA, Spiegelman D, Berkey CS, Danby FW, Rockett HH, Colditz GA, Willett WC, Holmes MD: Milk consumption and acne in teenaged boys. J Am Acad Dermatol 2008, 58:787-793. 
34. Jung JY, Yoon MY, Min SU, Hong JS, Choi YS, Suh DH: The influence of dietary patterns on acne vulgaris in Koreans. Eur J Dermatol 2010, 20:768-772

35. Melnik BC: Evidence for acne-promoting effects of milk and other insulinotropic dairy products. Nestle Nutr Workshop Ser Pediatr Program 2011, 67:131-145.

36. Sutcliffe $S$, Giovannucci $E$, Isaacs WB, Willett WC, Platz EA: Acne and risk of prostate cancer. Int J Cancer 2007, 121:2688-2692.

37. Melnik BC: Dietary intervention in acne: attenuation of increased mTORC1 signaling promoted by Western diet. Dermatoendocrinology 2012, 4:1.

38. Giovannucci E: Dietary influences of $1,25(\mathrm{OH}) 2$ vitamin $D$ in relation to prostate cancer: a hypothesis. Cancer Causes Control 1998, 9:567-582.

39. Koh KA, Sesso HD, Paffenbarger RS, Lee IM: Dairy products, calcium and prostate cancer risk. Br J Cancer 2006, 95:1582-1585.

40. Newmark HL, Heaney RP: Dairy products and prostate cancer risk. Nutr Cancer 2010, 62:297-299.

41. Tate PL, Bibb R, Larcom LL: Milk stimulates growth of prostate cancer cells in culture. Nutr Cancer 2011, 63:1361-1366.

42. Pettersson A, Kasperzyk JL, Kenfield SA, Richman EL, Chan JM, Willett WC, Stampfer MJ, Mucci LA, Giovannucci EL: Milk and dairy consumption among men with prostate cancer and risk of metastases and prostate cancer death. Cancer Epidemiol Biomarkers Prev 2012, 21:428-436.

43. Pópulo $H$, Lopes $J M$, Soares P: The mTOR signalling pathway in human cancer. Int J Mol Sci 2012, 13:1886-1918.

44. Inoki K, Ouyang H, Li Y, Guan KL: Signaling by target of rapamycin proteins in cell growth control. Microbiol Mol Biol Rev 2005, 69:79-100.

45. Bhaskar PT, Hay N: The two TORCs and Akt. Develop Cell 2007, 12:487-502

46. Wang $X$, Proud CG: Nutrient control of TORC1, a cell-cycle regulator. Cell 2009, 19:260-267.

47. Sengupta S, Peterson TR, Sabatini DM: Regulation of the mTOR complex 1 pathway by nutrients, growth factors, and stress. Mol Cell 2010, 40:310-322

48. Suzuki T, Inoki K: Spatial regulation of the mTORC1 system in amino acids sensing pathway. Acta Biochim Biophys Sin 2011, 43:671-679.

49. Wang $X$, Proud CG: mTORC1 signaling: what we still don't know. J Mol Cell Biol 2011, 3:206-220.

50. Shaw RJ: LKB1 and AMPK control of mTOR signalling and growth. Acta Physiol(Oxf.) 2009, 196:65-80.

51. Avruch J, Long X, Ortiz-Vega S, Rapley J, Papageorgiou A, Dai N: Amino acid regulation of TOR complex 1. Am J Physiol Endocrinol Metab 2009, 296:592-602.

52. Kimball SR, Jefferson LS: Signaling pathways and molecular mechanisms through which branched-chain amino acids mediate translational control of protein synthesis. J Nutr 2006, 136:227S-231S

53. Sancak $Y$, Peterson TR, Shaul YD, Lindquist RA, Thoreen CC, Bar-Peled $L$, Sabatini DM: The Rag GTPases bind raptor and mediate amino acid signaling to mTORC1. Science 2008, 320:1496-1501.

54. Dodd KM, Tee AR: Leucine and mTORC1: a complex relationship. Am J Physiol Endocrinol Metab 2012, 302:E1329-E1342.

55. Sancak Y, Bar-Peled L, Zoncu R, Markhard AL, Nada S, Sabatini DM: Ragulator- Rag complex targets mTORC1 to the lysosomal surface and is necessary for its activation by amino acids. Cell 2010, 141:290-303.

56. Goberdhan DC: Intracellular amino acid sensing and mTORC1-regulated growth: New ways to block an old target? Curr Opin Invest Drugs 2010, 11:1360-1367.

57. Inoki K, Li Y, Zhu T, Wu J, Guan KL: TSC2 is phosphorylated and inhibited by Akt and suppresses mTOR signalling. Nat Cell Biol 2002, 4:648-657.

58. Manning BD, Tee AR, Logsdon MN, Blenis J, Cantley LC: Identification of the tuberous sclerosis complex-2 tumor suppressor gene product tuberin as a target of the phosphoinositide-3-kinase/akt pathway. Mol Cell 2002, 10:151-162.

59. Tee AR, Fingar DC, Manning BD, Kwiatkowski DJ, Cantley LC, Blenis J: Tuberous sclerosis complex-1 and -2 gene products function together to inhibit mammalian target of rapamycin (mTOR)-mediated downstream signaling. Proc Natl Acad Sci USA 2001, 99:13571-13576.

60. Inoki K, Zhu T, Guan KL: TSC2 mediates cellular energy response to control cell growth and survival. Cell 2003, 115:577-590.

61. Gwinn DM, Shackelford DB, Egan DF, Mihaylova MM, Mery A, Vasquez DS, Turk BE, Shaw RJ: AMPK phosphorylation of raptor mediates a metabolic checkpoint. Mol Cell 2008, 30:214-226.
62. Hara K, Yonezawa K, Weng QP, Kozlowski MT, Belham C, Avruch J: Amino acid sufficiency and mTOR regulate p70 S6 kinase and elF-4EBP1 through a common effector mechanism. J Biol Chem 1998, 273:14484-14494.

63. Long $X$, Ortiz-Vega $S$, Lin $Y$, Avruch J: Rheb binding to mammalian target of rapamycin (mTOR) is regulated by amino acid sufficiency. J Biol Chem 2005, 280:23433-23436.

64. Nobukuni T, Joaquin M, Roccio M, Dann SG, Kim SY, Gulati P, Byfield MP, Backer JM, Natt F, Bos JL, Zwartkruis FJ, Thomas G: Amino acids mediate mTOR/raptor signaling through activation of class 3 phosphatidylinositol 3OH-kinase. Proc Natl Acad Sci USA 2005, 102:14238-14243.

65. Dennis MD, Baum Jl, Kimball SR, Jefferson LS: Mechanisms involved in the coordinate regulation of $\mathrm{mTORC} 1$ by insulin and amino acids. J Biol Chem 2011, 286:8287-8296.

66. Porstmann T, Santos CR, Lewis C, Griffiths B, Schulze A: A new player in the orchestra of cell growth: SREBP activity is regulated by mTORC1 and contributes to the regulation of cell and organ size. Biochem Soc Trans 2009, 37:278-283.

67. Peterson TR, Sengupta SS, Harris TE, Carmack AE, Kang SA, Balderas E, Guertin DA, Madden KL, Carpenter AE, Finck BN, Sabatini DM: mTOR complex 1 regulates lipin 1 localization to control the SREBP pathway. Cell 2011, 146:408-420

68. Zoncu R, Efeyan A, Sabatini DM: mTOR: from growth signal integration to cancer, diabetes and ageing. Nature Rev 2011, 12:21-35.

69. Proud CG: mTOR signalling in health and disease. Biochem Soc Trans 2011, 39:431-436.

70. Mieulet $\mathrm{V}$, Lamb RF: Tuberous sclerosis complex: liking cancer to metabolism. Trends Mol Med 2010, 16:329-335.

71. Dann SG, Selvaraj A, Thomas G: mTOR Complex 1-S6K1 signaling: at the crossroads of obesity, diabetes and cancer. Trends Mol Med 2007, 13:252-259

72. Shaw RJ, Cantley LC: Ras, $\mathrm{PI}(3) \mathrm{K}$ and mTOR signalling controls tumour cell growth. Nature 2006, 441:424-430.

73. Majumder PK, Sellers WR: Akt-regulated pathways in prostate cancer Oncogene 2005, 24:7465-7474.

74. Easton JB, Houghton PJ: mTOR and cancer therapy. Oncogene 2006 25:6436-6446

75. Gray IC, Stewart LM, Phillips SM, Hamilton JA, Gray NE, Watson GJ, Spurr NK, Snary D: Mutation and expression analysis of the putative prostate tumour- suppressor gene PTEN. Br J Cancer 1998, 78:1296-1300.

76. Taylor BS, Schultz N, Hieronymus H, Gopalan A, Xiao Y, Carver BS, Arora VK, Kaushik P, Cerami E, Reva B, Antipin Y, Mitsiades N, Landers T, Golgalev I, Major JE, Wilson M, Socci ND, Lash AE, Heguy A, Eastham JA, Scher HI, Reuter VE, Scardino PT, Sander C, Sawyers CL, Gerlad WL, for the MSKCC Prostate Cancer Oncogenome Group (PCOG): Integrative genomic profiling of human prostate cancer. Cancer Cell 2010, 18:11-22.

77. Um SH, D’Alessio D, Thomas G: Nutrient overload, insulin resistance, and ribosomal S6 kinase, S6K1. Cell Metab 2006, 3:393-402.

78. Inoki K, Li Y, XU T, Guan KL: Rheb GTPase is a direct target of TSC2 GAP activity and regulates mTOR signaling. Genes Dev 2003, 17:1829-1834.

79. Long $X$, Lin Y, Ortiz-Vega S, Yonezawa K, Avruch J: Rheb binds and regulates the mTOR kinase. Curr Biol 2005, 15:702-713.

80. Stambolic V, Suzuki A, de la Pompa JL, Brothers GM, Mirtsos C, Sasaki T, Ruland J, Penninger JM, Siderovski DP, Mak TW: Negative regulation of PKB/Akt- dependent cell survival by the tumor suppressor PTEN. Cell 1998, 95:29-39.

81. Whang YE, Wu X, Suzuki H, Reiter RE, Tran C, Vessella RL, Said JW, Isaacs WB, Sawyers CL: Inactivation of the tumor suppressor PTEN/MMAC1 in advanced human prostate cancer through loss of expression. Proc Natl Acad Sci USA 1998, 95:5246-5250.

82. Di Cristofano A, De Acetis M, Koff A, Cordon-Cardo C, Pandolfi PP: Pten and p27KIP1 cooperate in prostate cancer tumor suppression in the mouse. Nat Genet 2001, 27:222-224.

83. Trotman LC, Niki M, Dotan ZA, Koutcher JA, Di Cristofano A, Xiao A Khoo AS, Roy-Burman P, Greenberg NM, Van Dyke T, Cordon-Cardo C, Pandolfi PP: Pten dose dictates cancer progression in the prostate. PLoS Biol 2003, 1(3):E59

84. Mamane $Y$, Petroulakis E, LeBacquer O, Sonenberg N: mTOR, translation initiation and cancer. Oncogene 2006, 25:6416-6422. 
85. Guertin DA, Stevens DM, Saitoh M, Kinkel S, Crosby K, Sheen J-H, Mullholland DJ, Magnuson MA, Wu H, Sabatini DM: The mTOR complex 2 is required for the development of prostate cancer induced by Pten loss in mice. Cancer Cell 2009, 15:148-159.

86. Nardella C, Carracedo A, Altimonti A, Hobbs RM, Clohessy JG, Chen Z, Egia A, Fornari A, Fiorentino M, Loda M, Kozma SC, Thomas G, Cordon-Cardo C, Pandolfi PP: Differential requirement of mTOR in post-mitotic tissues and tumorigenesis. Sci Signal 2010, 2(55):ra2. doi:10.1126/scisignal.2000189.

87. Furic L, Rong L, Larsson O, Hervé Koumakpayi I, Yoshida K, Brueschke A, Petroulakis E, Robichaud N, Pollak M, Gaboury LA, Pandolfi PP, Saad F, Sonenberg N: elF4E phosphorylation promotes tumorigenesis and is associated with prostate cancer progression. Proc Natl Acad Sci USA 2010, 107:14134-14139.

88. Nardella C, Chen Z, Salmena L, Carracedo A, Alimonti A, Egia A, Carver B, Gerald W, Cordon-Cardo C, Pandolfi PP: Aberrant Rheb-mediated mTORC1 activation and Pten haploinsufficiency are cooperative oncogenic events. Genes Dev 2008, 22:2172-2177.

89. Clohessy JG, Reschke M, Pandolfi PP: Found in translation of mTOR signaling. Cell Res 2012, :1-4. May 29, doi:10.1038/cr.2012.85.

90. Thoreen CC, Chantranupong L, Keys HR, Wang T, Gray NS, Sabatini DM: A unifying model for mTORC1-mediated regulation of mRNA translation. Nature 2012, 485:109-116.

91. Hsieh AC, Liu Y, Edlind MP, Ingolia NT, Janes MR, Sher A, Shi EY, Stumpf CR, Christensen C, Bonham MJ, Wang S, Ren P, Martin M, Jessen K, Feldman ME, Weissman JS, Shokat KM, Rommel C, Ruggero D: The translational landscape of mTOR signalling steers cancer initiation and metastasis. Nature 2012, 485:55-64.

92. Chen ML, Xu PZ, Peng XD, Chen WS, Guuzman G, Yang Y, Di Cristofano A, Pandolfoi PP, Hay N: The deficiency of Akt 1 is sufficient to suppress tumor development in Pten+/- mice. Genes Develop 2006, 20:1569-1574

93. Majumder PK, Febbo PG, Bikoff R, Berger R, Xue Q, McMahon LM, Manola J, Brugarollas J, McDonnell TJ, Golub TR, Loda M, Lane HA, Sellers WR: mTOR inhibition reverses Akt-dependent prostate intraepithelial neoplasia through regulation of apoptotic and HIF-1 dependent pathways. Nat Med 2004, 10:594-601.

94. Zhang W, Zhu J, Efferson CL, Ware C, Tammam J, Angagaw M, Laskey J, Bettano KA, Kasibhatla S, Reilly JF, Sur C, Majumder PK: Inhibition of tumor progression by antiandrogens and $\mathrm{mTOR}$ inhibitor in a Pten-deficient mouse model of prostate cancer. Cancer Res 2009, 69:7466-7472.

95. Carver BS, Chapinski C, Wongvipat J, Hieronymus H, Chen Y, Chandarlapaty S, Arora VK, Le C, Koutcher J, Scher H, Scardino PT, Posen N, Sawyers CL: Reciprocal feedback regulation of PI3K and androgen receptor signaling in PTEN-deficient prostate cancer. Cancer Cell 2011, 19:575-586.

96. Xu Y, Chen SY, Ross KN, Balk SP: Androgens induce prostate cancer cell proliferation through mammalian target of rapamycin activation and posttranscriptional increases in cyclin D proteins. Cancer Res 2006 66:7783-7791

97. Wang Q, Bailey CG, Ng C, Tiffen J, Thoeng A, Minhas V, Lehman ML, Hendy SC, Buchanan G, Nelson CC, Rasko JE, Holst J: Androgen receptor and nutrient signaling pathways coordinate the demand for increased amino acid transport during prostate cancer progression. Cancer Res 2011, 71:7525-7536.

98. Teahan O, Bevan CL, Waxman J, Keun HC: Metabolic signatures of malignant progression in prostate epithelial cells. Int J Biochem Cell Biol 2011, 43:1002-1009.

99. Fang Z, Zhang T, Dizeyi N, Chen S, Wang H, Swanson KD, Cai C, Balk SP, Yan X: Androgen receptor enhances p27 degradation in prostate cancer cells through rapid and selective TORC2 activation. J Biol Chem 2012, 287:2090-2098.

100. Cao Y, Kamioka Y, Yokoi N, Kobayashi T, Hino O, Onodera M, Mochizuki N, Nakae J: Interaction of FoxO1 and TSC2 induces insulin resistance through activation of the mammalian target of rapamycin /p70 S6K pathway. J Biol Chem 2006, 52:40242-40251.

101. Chen CC, Jeon SM, Bhaskar PT, Nogueira V, Sundararajan D, Tonic I, Park Y, Hay N: FoxOs inhibit mTORC1 and activate Akt by inducing the expression of Sestrin3 and Rictor. Dev Cell 2010, 18:592-604

102. Hanahan D, Weinberg RA: Hallmarks of cancer: the next generation. Cell 2011, 144:646-674.
103. Orr JB: Influence of amount of milk consumption on the rate of growth of school children. B Med J 1928, 1:140-141.

104. Hoppe C, Mølgaard C, Michaelsen KF: Cow's milk and linear growth in industrialized and developing countries. Annu Rev Nutr 2006, 26:131-173

105. Wiley AS: Dairy and milk consumption and child growth: Is BMI involved? An analysis of NHANES 1999-2004. Am J Hum Biol 2010, 22:517-525.

106. Wiley AS: Milk intake and total dairy consumption: associations with early menarche in NHANES 1999-2004. PloS One 2011, 6:e14685.

107. Bounous G, Kongshavn PA, Taveroff A, Gold P: Evolutionary traits in human milk proteins. Med Hypotheses 1988, 27:133-140.

108. Davis TA, Nguyen HV, Garcia-Bravo R, Fiorotto ML, Jackson EM, Lewis DS, Lee DR, Reeds PJ: Amino acid composition of human milk is not unique. J Nutr 1994, 124:1126-1132.

109. Wiley AS: Cow milk consumption, insulin-like growth factor-l, and human biology: a life history approach. Am J Hum Biol 2012, 24:130-138.

110. Socha P, Grote V, Gruszfeld D, Janas R, Demmelmair H, Closa-Monasterolo R, Escribano Subías J, Scaglioni S, Verduci E, Dain E, Langhendries JP, Perrin E, Koletzko B, for the European Childhood Obesity Trial Study Group: Milk protein intake, the metabolic-endocrine response, and growth in infancy: data from a randomized clinical trial. Am J Clin Nutr 2011 94(suppl 6):1776S-1784S.

111. Axelsson IE, Ivarsson SA, Räihä NC: Protein intake in early infancy: effects on plasma amino acid concentrations, insulin metabolism, and growth. Pediatr Res 1989, 26:614-617.

112. Melnik BC: Leucine signaling in the pathogenesis of type 2 diabetes and obesity. World J Diabetes 2012, 3:38-53.

113. Melnik BC: Excessive leucine-mTORC1-signalling of cow milk-based infant formula: the missing link to understand early childhood obesity. J Obesity 2012, 2012:197653.

114. Cordain L, Watkins BA, Mann NJ: Fatty acid composition and energy density of foods available to African hominids. Evolutionary implications for human brain development. World Rev Nutr Diet 2001, 90:144-161.

115. Thissen JP, Pucilowska JB, Underwood LE: Differential regulation of insulin-like growth factor I (IGF-I) and IGF binding protein-1 messenger ribonucleic acids by amino acid availability and growth hormone in rat hepatocyte primary culture. Endocrinology 1994, 134:1570-1576.

116. Hoppe C, Udam TR, Lauritzen L, Molgaard C, Juul A, Michaelsen KF: Animal protein intake, serum insulin-like growth factor I, and growth in healthy 2.5-y-old Danish children. Am J Clin Nutr 2004, 80:447-452.

117. Hoppe C, Molgaard C, Juul A, Michaelsen KF: High intakes of skimmed milk, but not meat, increase serum IGF-I and IGFBP-3 in eight-year-old boys. Eur J Clin Nutr 2004, 58:1211-1216.

118. Hoppe C, Molgaard C, Dalum C, Vaag A, Michaelsen KF: Differential effects ofcasein versus whey on fasting plasma levels of insulin, IGF-1 and IGF-1/IGFBP-3: results from a randomized 7-day supplementation study in prepubertal boys. Eur J Clin Nutr 2009, 63:1076-1083.

119. Tazearslan C, Hunag H, Barzilai N, Suh Y: Impaired IGF1R signaling in cells expressing longevity-associated human IGF1R alleles. Aging Cell 2011, 10:551-554.

120. Steuerman R, Shevah O, Laron Z: Congenital IGF1 deficiency tends to confer protection against post-natal development of malignancies. Eur $J$ Endocrinol 2011, 164:485-489.

121. Guevara-Aguirre J, Balasubramanian P, Guevara-Aguirre M, Wie M, Madia F, Cheng CW, Hwang D, Martin-Montalvo A, Saavedra J, Ingles S, de Cabo R, Cohne P, Longo VD: Growth hormone receptor deficiency is associated with a major reduction in proaging signaling, cancer, and diabetes in humans. Sci Transl Med 2011, 3:70ra13.

122. Maiese K, Chong ZZ, Shang YC, Hou J: Clever cancer strategies with FoxO transcription factors. Cell Cycle 2008, 7:3829-3839.

123. Major JM, Laughlin GA, Kritz-Silverstein D, Wingard DL, Barrett-Connor E: Insulin-like growth factor-I and cancer mortality in older men. J Clin Endocrinol Metab 2010, 95:1054-1059.

124. Dunger DB, Ong KK, Sandhu MS: Serum insulin-like growth factor-I levels and potential risk of type 2 diabetes. Horm Res 2003, 60(suppl 3):131-135.

125. Hara N: Prostate carcinogenesis with diabetes and androgen-deprivationtherapy- related diabetes: an update. Exp Diabetes Res 2012, 2012:801610.

126. Stattin P, Bylund A, Rinaldi S, Biessy C, Déchaud H, Stenman UH, Egevad L, Riboli E, Hallmans G, Kaaks R: Plasma insulin-like growth factor-I, 
insulin-like growth factor-binding proteins, and prostate cancer risk: a prospective study. J Natl Cancer Inst 2000, 92:1910-1907.

127. Renehan AG, Zwahlen M, Minder C, O'Dwyer ST, Shalet SM, Egger M: Insulin-like growth factor (IGF)-I, IGF binding protein-3, and cancer risk: systematic review and meta-regression analysis. Lancet 2004, 363:1353.

128. Clayton PE, Banerjee I, Murray PG, Renehan AG: Growth hormone, the insulin-like growth factor axis, insulin and cancer risk. Nature Rev Endocrinol 2011, 7:11-24.

129. Norat T, Dossus L, Rinaldi S, Overvad K, Grønbaek H, Tjønneland A, Halkjær J, Dossus L, Boeing H, Kröger J, Trichopoulou A, Zylis D, Trichopoulos D, Boutron-Ruault MC, de Lauzon-Guillain B, Clavel-Chapelon F, Palli D, Berrino F, Panico S, Tumino R, Sacerdote C, Bueno-de-Mesquita HB, van Gils CH, Peeters PH, Gram IT, Rodríguez L, Jakszyn P, Molina-Montes E, Navarro C, Barricarte A, Larrañaga N, Khaw KT, Rodwell S, Rinaldi S, Slimani N, Norat T, Gallo V, Riboli E, Kaaks R: Diet, serum insulin-like growth factor-I and IGF-binding protein-3 in European women. Eur J Clin Nutr 2007, 6:91-98

130. Crowe FL, Key TJ, Allen NE Appleby PN, Roddam A, Overvad K, Grønbaek H, Tjønneland A, Halkjaer J, Dossus L, Boeing H, Kröger J, Trichopoulou A, Dilis V, Trichopoulos D, Boutron-Ruault MC, De Lauzon B, Clavel-Chapelon F, Palli D, Berrino F, Panico S, Tumino R, Sacerdote C, Bueno-de-Mesquita HB, Vrieling A, van Gils CH, Peeters PH, Gram IT, Skeie G, Lund E, Rodríguez L, Jakszyn P, Molina- Montes E, Tormo MJ, Barricarte A, Larrañaga N, Khaw KT, Bingham S, Rinaldi S, Slimani N, Norat T, Gallo V, Riboli E, Kaaks R: The association between diet and serum concentrations of IGF-I, IGFBP-1, IGFBP-2, and IGFBP-3 in the European Prospective Investigation into Cancer and Nutrition. Cancer Epidemiol Biomarkers Prev 2009, 18:1333-1340

131. Young NJ, Metcalfe C, Gunnell D, Rowlands MA, Lane JA, Gilbert R, Avery KNL, Davis M, Neal DE, Hamdy FC, Donovan J, Martin RM, Holly JMP: A cross-sectional analysis of the association between diet and insulin-like growth factor (IGF)-I, IGF-II, IGF-binding protein (IGFBP)-2, and IGFBP-3 in men in the United Kingdom. Cancer Causes Control 2012, 23:907-917.

132. Denley A, Cosgrove $\sqcup$, Booker GW, Wallace JC, Forbes BE: Molecular interactions of the IGF system. Cytokine Growth Factor Rev 2005, 16:421-439.

133. Melnik BC, John SM, Schmitz G: Over-stimulation of insulin/IGF-1 signaling by Western diet promotes diseases of civilization: lessons learnt from Laron syndrome. Nutr Metab (Lond) 2011, 8:41.

134. Xu G, Kwon G, Marsahll CA, Lin TA, Lawrence JC, McDaniel ML: Branchedchain amino acids are essential in the regulation of PHAS-I and p70 S6 kinase by pancreatic $\beta$-cells. A possible role in protein translation and mitogenic signaling. J Biol Chem 1998, 273:18178-28184

135. Yang J, Chi Y, Burkhardt BR, Guan Y, Wolf BA: Leucine metabolism in regulation of insulin secretion from pancreatic beta cells. Nutr Rev 2010, 68:270-279

136. McDaniel ML, Marshall CA, Pappan KL, Kwon G: Metabolic and autocrine regulation of the mammalian target of rapamycin by pancreatic beta-cells. Diabetes 2002, 51:2877-2885.

137. Xu G, Kwon G, Cruz WS, Marshall CA, McDaniel ML: Metabolic regulation by leucine of translation initiation through the mTOR-signaling pathway by pancreatic beta-cells. Diabetes 2001, 50:353-360.

138. Rich-Edwards JW, Ganmaa D, Pollak MN, Nakamoto EK, Kleinman K, Willett WC, Frazier A, Tserendolgor: Milk consumption and the prepubertal somatotropic axis. Nutr J 2007, 6:28.

139. Nilsson M, Holst JJ, Björck IM: Metabolic effects of amino acid mixtures and whey protein in healthy subjects: studies using glucose-equivalent drinks. Am J Clin Nutr 2007, 85:996-1004.

140. Hoyt G, Hickey MS, Cordain L: Dissociation of the glycaemic and insulinaemic responses to whole and skimmed milk. Br J Nutr 2005, 93:175-177

141. Salehi A, Gunnerud U, Muhammed SJ, Ostman E, Holst JJ, Björck L, Rorsman P: The insulinogenic effect of whey protein is partially mediated by a direct effect of amino acids and GIP on beta-cells. Nutr Metab (Lond) 2012, 9(1):48.

142. Manders RJ, Prate SF, Meex RC, Koopman R, de Roos AL, Wagenmakers AJ, Saris WH, van Loon LJ: Protein hydrolysate/leucine co-ingestion reduces the prevalence of hyperglycemia in type 2 diabetic patients. Diabetes Care 2006, 29:2721-2722
143. Hoppe C, Mølgaard C, Vaag A, Barkholt V, Michaelsen KF: High intakes of milk, but not meat, increase s-insulin and insulin resistance in 8-year-old boys. Eur J Clin Nutr 2005, 59:393-398.

144. Zick Y: Ser/Thr phosphorylation of IRS proteins: a molecular basis for insulin resistance. SCi STKE 2005, 268:pe4.

145. Venkateswaran V, Haddad AQ, Fleshner NE, Fan R, Sugar LM, Nam R Klotz LH, Pollak M: Association of diet-induced hyperinsulinemia with accelerated growth of prostate cancer (LNCaP) xenografts. J Natl Cancer Inst 2007, 99:1793-1800.

146. Weinstein D, Simon M, Yeheezkel E, Laron Z, Werner H: Insulin analogues diplay IGF-1-like mitogenic and anti-apoptotic activities in cultured cancer cells. Diabetes Metab Res Rev 2009, 25:41-49.

147. Moore T, Carbajal S, Beltran L, Perkins SN, Yakar S, LeRoith D, Hursting SD, DiGiovanni J: Reduced susceptibility to two-stage skin carcinogenesis in mice with low circulating insulin-like growth factor-l levels. Cancer Res 2008, 68:3680-3688.

148. Moore T, Beltran L, Carbajal S, Strom S, Traag J, Husting SD, DiGiovanni J: Dietary energy balance modulates signalling through the Akt/mammalian target of rapamycin pathways in multiple epithelial tissues. Cancer Prev Res 2008, 1:65-76

149. Zhu ML, Kyrianou N: Androgen receptor and growth factor signaling cross-talk in prostate cancer cells. Endocr Relat Cancer 2008, 15:841-849.

150. Fontana L, Weiss EP, Villareal DT, Klein S, Holloszy JO: Long-term effects of calorie or protein restriction on serum IGF-1 and IGFBP-3 concentrations in humans. Aging Cell 2008, 7:681-687.

151. Farnfield MM, Carey KA, Gran P, Trenerry MK, Cameron-Smith D: Whey protein ingestion activates mTOR-dependent signalling after resistance exercise in young men: A double-blinded randomized controlled trial. Nutrients 2009, 1:263-275.

152. Crozier SJ, Kimball SR, Emmert SW, Anthony JC, Jefferson LS: Oral leucine administration stimulates protein synthesis in rat skeletal muscle. J Nutr 2005, 135:376-382

153. Long W, Saffer L, Wei L, Barrett EJ: Amino acids regulate skeletal muscle PHAS-I and p70S6-kinase phosphorylation independently of insulin Am J Physiol Endocrinol Metab 2000, 279:301-306.

154. Gingras AC, Gygi SP, Raught B, Polakiewicz RD, Abraham RT, Hoekstra MF, Aebersold R, Sonenberg N: Regulation of 4E-BP1 phosphorylation: a novel two- step mechanism. Genes Dev 1999, 13:1422-1437.

155. Millward DJ, Layman DK, Tomé D, Schaafsma G: Protein quality assessment: impact of expanding understanding of protein and amino acid needs for optimal health. Am J Clin Nutr 2008 87:1576S-1581S

156. Holt S, Brand Miller J, Petocz P: An insulin index of foods: the insulin demand generated by 1000-kJ portions of common foods. Am J Clin Nutr 1997, 66:1264-1276.

157. Frassetto LA, Schloetter M, Mietus-Synder M, Morris RC Jr, Sebastian A: Metabolic and physiologic improvements from consuming a paleolithic, hunter-gatherer type diet. Eur J Clin Nutr 2009, 63:947-955.

158. Agostoni C, Turck D: Is cow's milk harmful to a child's health? J Pediatr Gastroenterol Nutr 2011, 53:594-600

159. Qin LQ, Wang PY, Kaneko T, Hoshi K, Sato A: Estrogen: one of the risk factors in milk for prostate cancer. Med Hypotheses 2004, 62:133-142.

160. Kruithof-Dekker IG, Tetu B, Janssen PJ, Van der Kwast TH: Elevated estrogen receptor expression in human prostatic stromal cells by androgen ablation therapy. J Urol 1996, 156:1194-1197.

161. Malekinejad H, Scherpenisse P, Bergwerff AA: Naturally occurring estrogens in processed milk and in raw milk (from gestated cows). J Agric Food Chem 2006, 54:9785-9791.

162. Farlow DW, Xu X, Veenstra TD: Quantitative measurement of endogenous estrogen metabolites, risk-factors for development of breast cancer, in commercial milk products by LC-MS/MS. J Chromatography B Analyt Technol Biomed Life Sci 2009, 877:1327-1334.

163. Danby FW: Acne, dairy and cancer. The 5alpha-P link. Dermatoendocrinology 2009, 1:9-13.

164. Maruyama K, Oshima T, Ohyama K: Exposure to exogenous estrogen through intake of commercial milk produced from pregnant cows. Pediatr Internat 2010, 52:33-38.

165. Santti R, Newbold RR, Makela S, Pylkkanen L, Mclachlan JA: Developmental estrogenization and prostatic neoplasia. Prostate 1994, 24:67-78.

166. Bosland MC, Mahmoud AM: Hormones and prostate carcinogenesis: Androgens and estrogens. J Carcinog 2011, 10:33. 
167. DeKlerk DP, Coffey DS, Ewing LL, McDermott IR, Reiner WG, Robinson $C H$, Scott WW, Strandberg JD, Talalay P, Walsh PC, Wheaton LG, Zirkin BR: Comparison of spontaneous and experimentally induced canine prostatic hyperplasia. J Clin Invest 1979, 64:842-849.

168. Coffey DS: Similarities of prostate and breast cancer: Evolution, diet, and estrogens. Urology 2001, 57(Suppl 4A):31-33.

169. Torlakovic E, Lilleby W, Torlakovic G, Fosså SD, Chibbar R: Prostate carcinoma expression of estrogen receptor-beta as detected by PPG5/10 antibody has positive association with primary Gleason grade and Gleason score. Hum Pathol 2002, 33:646-651.

170. Dunsmuir WD, Gillett CE, Meyer LC, Young MP, Corbishley C, Eeles RA, Kirby RS: Molecular markers for predicting prostate cancer stage and survival. BJU Int 2000, 86:869-878.

171. Asgari M, Morakabati A: Estrogen receptor beta expression in prostate adenocarcinoma. Diagn Pathol 2011, 6:61.

172. Shennan DB, Thomson J, Gow IF, Travers MT, Barber MC: L-leucine transport in human breast cancer cells (MCF-7 and MDA-MB-231): kinetics, regulation by estrogen and molecular identity of the transporter. Biochim Biophys Acta 2004, 1664:206-216.

173. Qin LQ, Xu JY, Wang PY, Ganmaa D, Li J, Wang J, Kaneko T, Hoshi K, Shirai T, Sato A: Low-fat milk promotes the development of 7,12-dimethylbenz(a) anthracene (DMBA)-induced mammary tumors in rats. Int J Cancer 2004 110:491-496.

174. Ma DF, Katoh $R$, Zhou $H$, Wang PY: Promoting effects of milk on the development of 7,12-diemethylbenz(a)anthracene (DMBA)-induced mammary tumors in rats. Acta Histochem Cytochem 2007, 40:61-67.

175. Ganmaa D, Tezuka H, Enkhmaa D, Hoshi K, Sato A: Commercial cows'milk has uterotrophic activity on the uteri of young ovariectomized rats and immature rats. Int J Cancer 2006, 118:2363-2365.

176. Chang SB, Miron P, Miron A, Iglehart JD: Rapamycin inhibits proliferation of estrogen-receptor-positive breast cancer cells. J Surg Res 2007, 138:37-44.

177. Tewari R, Rajender S, Natu SM, Dalela D, Goel A, Goel MM, Tandon P: Diet, obesity, and prostate health: Are we missing the link? J Androl 2012, Feb 9 Epubahead of print.

178. Gronberf H, Damber L, Damber JE: Total food consumption and body mass index in relation to prostate cancer risk: a case-control study in Sweden with prospectively collected exposure data. J Urol 1996, 155:969-974.

179. Freeland SJ, Platz EA: Obesity and prostate cancer: making sense out of apparently conflicting data. Epidemiol Rev 2007, 29:88-97.

180. Gong Z, Neuhouser ML, Goodman PJ, Albanes D, Chi C, Hsing AW, Lippman SM, Platz EA, Pollak MN, Thompson IM, Kristal AR: Obesity, diabetes and risk of prostate cancer: results from the Prostate Cancer Prevention Trial. Cancer Epidemiol Biomarkers Prev 2006, 15:1977-1983.

181. Discacciati A, Orsini N, Wolk A: Body mass index and incidence of localized andadvanced prostate cancer - a dose-response meta-analysis of prospective studies. Ann Oncol 2012, Jan 6 [Epub ahead of print].

182. Fowke JH, Motley SS, Concepcion RS, Penson DF, Barocas DA: Obesity, body composition, and prostate cancer. BMC Cancer 2012, 12:23.

183. Lynch CJ, Fox HL, Vary TC, Jefferson LS, Kimball SR: Regulation of amino acid- sensitive TOR signaling by leucine analogues in adipocytes. J Cell Biochem 2000, 77:234-251.

184. Lynch CJ: Role of leucine in the regulation of mTOR by amino acids: revelations from structure-activity studies. J Nutr 2001, 131:861S-865S

185. Pham PT, Heydrick SJ, Fox HL Kimball SR, Jefferson LS Jr, Lynch CJ: Assessment of cell-signaling pathways in the regulation of mammalian target of rapamycin (mTOR) by amino acids in rat adipocytes. $J$ Cell Biochem 2000, 79:427-441.

186. Kim JE, Chen J: Regulation of peroxisome proliferator-activated receptor- $\gamma$ activity by mammalian target of rapamycin and amino acids in adipogenesis. Diabetes 2004, 53:2748-2756.

187. Fox HL, Kimball SR, Jefferson LS, Lynch CJ: Amino acids stimulate phosphorylation of p70S6k and organization of rat adipocytes into multicellular clusters. Am J Physiol Cell Physiol 1998, 274:C206-C213.

188. Fox HL, Pham PT, Kimball SR, Jefferson LS, Lynch CJ: Amino acid effects on translational repressor $4 \mathrm{E}-\mathrm{BP} 1$ are mediated primarily by L-leucine in isolated adiopocytes. Am J Physiol Cell Physiol 1998, 275:C1232-C1238.
189. Carnevalli LS, Masuda K, Frigerio F, Le Bacquer O, Um SH, Gandin V, Topisirovic I, Sonenberg N, Thomas G, Kozma SC: S6K1 plays a critical role in early adipocyte differentiation. Dev Cell 2010, 18:763-774.

190. Boura-Halfon S, Zick Y: Phosphorylation of IRS proteins, insulin action, and insulin resistance. Am J Physiol Endocrinol Metab 2009, 296:E581-E591.

191. Krebs M, Brunmair B, Brehm A, Artwohl M, Szendroedi J, Nowotny P, Roth E, Fürnsinn C, Promintzer M, Anderwald C, Bischof M, Roden M: The mammalian target of rapamycin pathway regulates nutrient-sensitive glucose uptake in man. Diabetes 2007, 56:1600-1607.

192. Tremblay F, Krebs M, Dombrowski L, Brehm A, Bernroider E, Roth $E$, Nowotny P, Waldhäusl W, Marette A, Roden M: Overactivation of S6 kinase 1 as a cause of human insulin resistance during increased amino acid availability. Diabetes 2005, 54:2674-2684.

193. Johnson S, Karam JH, Levin SR, Grodsky GM, Forsham PH: Hyperinsulin response to oral leucine in obesity and acromegaly. J Clin Endocrinol Metab 1973, 37:431-435.

194. Vikram A, Jena G: Diet-induced hyperinsulinemia accelerates growth of androgen-independent PC-3 cells in vitro. Nutr Cancer 2012, 64:121-127.

195. Felig P, Marliss E, Cahill GF Jr: Plasma amino acid levels and insulin secretion in obesity. N Engl J Med 1969, 281:811-816.

196. Rosenthal J, Angel A, Farkas J: Metabolic fate of leucine: a significant sterol precursor in adipose tissue and muscle. Am J Physiol 1974 226:411-418.

197. She P, Van Horn C, Reid T, Hutson SM, Cooney RN, Lynch CJ: Obesityrelated elevations in plasma leucine are associated with alterations in enzymes involved in branched-chain amino acid metabolism. Am J Physiol Endocrinol Metab 2007, 293:E1552-E1563.

198. Herman MA, She P, Peroni OD, Lynch CJ, Kahn BB: Adipose tissue branched chain amino acid (BCAA) metabolism modulates circulating BCAA levels. J Biol Chem 2010, 285:11348-11356.

199. She P, Reid TM, Bronson SK, Vary TC, Hajnal A, Lynch CJ, Hutson SM: Disruption of BCATm in mice leads to increased energy expenditure associated with the activation of a futile protein turnover cycle. Cell Metab 2007, 6:181-194.

200. Liu EY, Ryan KM: Autophagy and cancer - issues we need to digest. J Cell Sci 2012, 125:2349-2358.

201. Jegga AG, Schneider L, Ouyang $X$, Zhang J: Systems biology of the autophagy- lysosomal pathway. Autophagy 2011, 5:477-489.

202. Jin S, White E: Role of autophagy in cancer: management of metabolic stress. Autophagy 2007, 3:28-31.

203. Lozy F, Karantza V: Autophagy and cancer cell metabolism. Sem Cell Dev Biol 2012, 23:395-401.

204. Chang YY, Juhász G, Goraksha-Hicks P, Arsham AM, Mallin DR, Muller LK, Neufeld TP: Nutrient-dependent regulation of autophagy through the target of rapamycin pathway. Biochem Soc Trans 2009, 37:232-236.

205. Mathew R, Karantza-Wadsworth V, White E: Role of autophagy in cancer. Nat Rev Cancer 2007, 7:961-967.

206. DiPaola RS, Dvorzhinski D, Thalasila A, Garikapaty V, Doram D, May M, Bray K, Mathew R, Beaudoin B, Karp C, Stein M, Foran DJ, White E: Therapeutic starvation and autophagy in prostate cancer: a new paradigm for targeting metabolism in cancer therapy. Prostate 2008, 68:1743-1752

207. Lozy F, Karantza V: Autophagy and cancer cell metabolism. Semin Cell Dev Biol 2012, Jan 18 [Epub ahead of print].

208. Kaini RR, Sillerud LO, Zhaorigetu S, Hu CA: Autophagy regulates lipolysis and cell survival through lipid droplet degradation in androgen-sensitive prostate cancer cells. Prostate 2012, doi:10.1002/pros.22489. Epub ahead of print.

209. Meijer AJ: Amino acid regulation of autophagosome formation. Methods Mol Biol 2008, 445:89-109.

210. Yan X, Sun Q, Ji J, Zhu Y, Liu Z, Zhong Q: Reconstitution of leucine-mediated autophagy via the MTORC1 -Barkor pathway in vitro. Autophagy 2012, 8:213-221.

211. Cao C, Subhawong T, Albert JM, Kim KW, Geng L, Sekhar KR, Gi YJ, Lu B: Inhibition of mammalian target of rapamycin or apoptotic pathway induces autophagy and radiosensitizes PTEN null prostate cancer cells. Cancer Res 2006, 66:10040-10047.

212. Chiu HW, Fang WH, Chen YL, Wu MD, Yuan MD, Ho SY, Wang YJ: Monascuspiloin enhances the radiation sensitivity of human prostate cancer cells by stimulating endoplasmic reticulum stress and inducing autophagy. PLOS ONE 2012, 7:e40462. 
213. Costa MM, Violato NM, Taboga SR, Góes RM, Bosqueiro JR: Reduction of insulin signalling pathway IRS-1/IRS-2/AKT/mTOR and decrease of epithelial cell proliferation in the prostate of glucocorticoid-treated rats. Int J Exp Pathol 2012, 93:188-195.

214. Shimizu N, Yoshikawa N, Ito N, Maruyama T, Suzuki Y, Takeda S, Nishitani S, Takehana K, Sano M, Fukuda K, Suematsu M, Morimoto C, Tanaka H: Crosstalk between glucocorticoid receptor and nutritional sensor mTOR in skeletal muscle. Cell Metab 2011, 13:170-182.

215. Brugarolas J, Lei K, Hurley RL, Manning BD, Reiling JH, Hafen E, Witters LA, Ellisen LW, Kaelin WG Jr: Regulation of mTOR function in response to hypoxia by REDD1 and the TSC1/TSC2 tumor suppressor complex. Genes Dev 2004, 18:2893-2904.

216. DeYoung MP, Horak P, Sofer A, Sgroi D, Ellisen LW: Hypoxia regulates TSC1/2-mTOR signaling and tumor suppression through REDD1-mediated 14-3-3 shuttling. Genes Dev 2008, 22:239-251.

217. Wang H, Kubica N, Ellisen LW, Jefferson LS, Kimball SR: Dexamethasone represses signaling through the mammalian target of rapamycin muscle cells by enhancing expression of REDD1. J Biol Chem 2006, 281:39128-39134.

218. Gray S, Wang B, Orihuela Y, Hong EG, Fisch S, Haldar S, Cline GW, Kim JK, Peroni OD, Kahn BB, Jain MK: Regulation of gluconeogenesis by Krüppel-like factor 15. Cell Metab 2007, 5:305-312.

219. Clements A, Gao B, Yeap SHO, Wong MKY, Ali SS, Gurney H: Metformin in prostate cancer: two for the price of one. Ann Oncol 2011, 22:2556-2560

220. Currie CJ, Poole CD, Jenkins-Jones S, Gale EA, Johnson JA, Morgan CL: Mortality after incident cancer in people with and without type 2 diabetes. Diabetes Care 2012, 35:299-304.

221. He XX, Tu SM, Lee MH, Yeung SC: Thiazolidinediones and metformin associated with improved survival of diabetic prostate cancer patients. Ann Oncol 2011, 22:2640-2645.

222. Ben Sahra I, Laurent K, Loubat A, Giorgett-Peraldi S, Colosetti P, Auberger P, Tanti JF, Le Marchand-Brustel Y, Bost F: The antidiabetic drug metformin exerts an antitumorial effect in vitro and in vivo through a decrease of cyclin D1 level. Oncogene 2008, 27:3576-3586.

223. Hardie DG: Role of AMP-activated protein kinase in the metabolic syndrome and in heart disease. FEBS Lett 2008, 582:81-89.

224. Xie J, Ponuwei GA, Moore CE, Willars GB, Tee AR, Herbert TP: CAMP inhibits mammalian target of rapamycin complex-1 and -2 (mTORC1 and 2) by promoting complex dissociation and inhibiting mTOR kinase activity. Cell Signal 2011, 23:1927-1935.

225. Ben Sahra I, Laurent K, Giuliano S, Larbret F, Ponzio G, Gounon P, Le Marchand- Brustel Y, Giorgetti-Peraldi S, Cormont M, Bertolotto C, Deckert M, Auberger P, Tanti JF, Bost F: Targeting cancer cell metabolism: the combination of metformin and 2-dexoyglucose induces p53-dependent apoptosis in prostate cancer cells. Cancer Res 2010, 70:2465-2475.

226. Kalender A, Selvaraj A, Kim SY, Gulati P, Brûlé S, Viollet B, Kemp BE, Bardeesy N, Dennis P, Schlager JJ, Marette A, Kozma SC, Thomas G: Metformin, independent of AMPK, inhibits mTORC1 in a RAG GTPase-dependent manner. Cell Metab 2010, 11:390-398.

227. Kim E, Goraksha-Hicks P, Li L, Neufeld TP, Guan KL: Regulation of TORC1 by Rag GTPases in nutrient response. Nat Cell Biol 2008, 10:935-945.

228. Chan JM, Gann PH, Giovannucci EL: Role of diet in prostate cancer development and progression. J Clin Oncol 2005, 23:8152-8160.

229. Sonn GA, Aronson W, Litwin MS: Impact of diet on prostate cancer: a review. Prostate Cancer Prostatic Dis 2005, 8:304-310.

230. Kristal AR, Cohen JH, Qu P, Stanford JL: Association of energy, fat, calcium, and vitamin D with prostate cancer risk. Cancer Epidemiol Biomarkers Prev 2002, 11:719-725.

231. Giovannucci E, Ascherio A, Rimm EB, Stampfer MJ, Colditz GA, Willett WC: Intake of carotenoids and retinol in relation to risk of prostate cancer. J Natl Cancer Inst 1995, 87:1767-1776.

232. Graham S, Haughey B, Marshall J, Priore R, Byers T, Rzepka T, Mettlin C, Pontes JE: Diet in the epidemiology of carcinoma of the prostate gland. J Natl Cancer Inst 1983, 70:687-692.

233. Kolonel LN, Hankin JH, Whittemore AS, Wu AH, Gallaher RP, Wilkens LR, John EM, Howe GR, Dreon DM, West DW, Paffenbarger RS: Vegetables, fruits, legumes and prostate cancer: a multi-ethnic case-control study. Cancer Epidemiol Biomarkers Prev 2000, 9:795-804.
234. Marques FZ, Markus MA, Morris BJ: Resveratrol: cellular actions of a potent natural chemical that confers a diversity of health benefits. Int J Biochem Cell Biol 2009, 41:2125-2128.

235. Zhou H, Luo Y, Huang S: Updates of mTOR inhibitors. Anticancer Agents Med Chem 2010, 10:571-581.

236. Jiang H, Shang X, Wu H, Gautam SC, Al-Holou S, Li C, Kuo J, Zhang L, Chopp M: Resveratrol downregulates PI3K/Akt/mTOR signaling pathways in human U251 glioma cells. J Exp Ther Oncol 2009, 8:25-33.

237. Brito PM, Devillard R, Negre-Salvayre A, Almeida LM, Dinis TC, Salvayre R, Augé N: Resveratrol inhibits the mTOR mitogenic signaling evoked by oxidized LDL in smooth muscle cells. Atherosclerosis 2009, 205:126-134.

238. Lin JN, Lin VC, Rau KM, Shieh PC, Kuo DH, Shieh JC, Chen WJ, Tsai SC, Way TD: Resveratrol modulates tumor cell proliferation and protein translation via SIRT1-dependent AMPK activation. J Agric Food Chem 2010, 58:1584-1592.

239. Fröjdjö S, Cozzone D, Vidal H, Pirola L: Resveratrol is a class IA phosphoinositide 3-kinase inhibitor. Biochem J 2007, 406:511-518.

240. Zhang Q, Kelly AP, Wang L, French SW, Tang X, Duong HS, Messadi DV, Le AD: Green tea extract and (-)-epigallocatechin-3-gallate inhibit mast cell-stimulated type I collagen expression in keloid fibroblasts via blocking PI-3 K/Akt signaling pathways. J Invest Dermatol 2006, 126:2607-2613.

241. Van Aller GS, Carson JD, Tang W, Peng H, Zhao L, Copeland RA, Tummino PJ, Luo L: Epigallocatechin gallate (EGCG), a major component of green tea, is a dual phosphoinositide-3-kinase/mTOR inhibitor. Biochem Biophys Res Commun 2011, 406:194-199.

242. Beevers CS, Chen L, Liu L, Luo Y, Webster NJ, Huang S: Curcumin disrupts the mammalian target of rapamycin-raptor complex. Cancer Res 2009, 69:1000-1008

243. Anastasius N, Boston S, Lacey M, Storing N, Whitehead SA: Evidence that low- dose, long-term genistein treatment inhibits oestradiol-stimulated growth in MCF-7 cells by down-regulation of the PI3-kinase/Akt signalling pathway. J Steroid Biochem Mol Biol 2009, 116:50-55.

244. Nakamura Y, Yogosawa S, Izutani Y, Watanabe H, Otsuji E, Sakai T: A combination of indol-3-carbinol and genistein synergistically induces apoptosis in human colon cancer HT-29 cells by inhibiting Akt phosphorylation and progression of autophagy. Mol Cancer 2009, 8:100.

245. Kong D, Banerjee S, Huang W, Li Y, Wang Z, Kim HR, Sarkar FH: Mammalian target of rapamycin repression by 3,3-diindolylmethane inhibits invasion and angiogenesis in platelet-derived growth factor-D-overexpressing PC3 cells. Cancer Res 2008, 68:1927-1934.

246. Reinke A, Chen JC, Aronova S, Powers T: Caffeine targets TOR complex I and provides evidence for a regulatory link between the FRB and kinase domains of Tor1p. J Biol Chem 2006, 281:31616-31626.

247. Goel A, Kunnumakkara AB, Aggarwal BB: Curcumin as "Curecumin": from kitchen to clinic. Biochem Pharmacol 2008, 75:787-809.

248. Johnson SM, Gulhati P, Arrieta I, Wang X, Uchida T, Gao T, Evers BM: Curcumin inhibits proliferation of colorectal carcinoma by modulating Akt/mTOR signaling. Anticancer Res 2009, 29:3185-3190.

249. Beevers CS, Li F, Liu L, Huang S: Curcumin inhibits the mammalian target of rapamycin-mediated signaling pathways in cancer cells. Int J Cancer 2006, 119:757-764

250. Banerjee S, Kong D, Wang Z, Bao B, Hillman GG, Sarkar FH: Attenuation of multi-targeted proliferation-linked signaling by 3,3'-diindolylmethane (DIM): from bench to clinic. Mutat Res 2011, 728:47-66.

251. Connors SK, Chornokur G, Kumar NB: New insights into the mechanisms of green tea catechins in the chemoprevention of prostate cancer. Nutr Cancer 2012, 64:4-22.

252. Henning SM, Wang P, Heber D: Chemopreventive effects of tea in prostate cancer: green tea versus black tea. Mol Nutr Food Res 2011, 55:905-920

253. Yang CS, Wang H, Li GX, Yang Z, Guan F, Jin H: Cancer prevention by tea: Evidence from laboratory studies. Pharmacol Res 2011, 64:113-122.

254. Henning SM, Aronson W, Niu Y, Conde F, Lee NH, Seeram NP, Lee RP, Lu J, Harris DM, Moro A, Hong J, Pak-Shan L, Barnard RJ, Ziaee HG, Csathy G, Go VL, Wang H, Heber D: Tea polyphenols and theaflavins are present in prostate tissue of humans and mice after green and black tea consumption. J Nutr 2006, 136:1839-1843.

255. Chen Q, Ganapathy S, Singh KP, Shankar S, Srivastava RK: Resveratrol induces growth arrest and apoptosis through activation of FOXO transcription factors in prostate cancer cells. PIOS ONE 2010, 5:e15288. 
256. Olsen SF, Halldorsson TI, Willett WC, Knudsen VK, Gillman MW, Mikkelsen TB, Olsen J, and the NUTRIX Consortium: Milk consumption during pregnancy is associated with increased size at birth: prospective cohort study. Am J Clin Nutr 2007, 86:1104-1110.

257. Roos S, Powell TL, Jansson T: Placental mTOR links maternal nutrient availability to fetal growth. Biochem Soc Trans 2009, 37:295-298.

258. Roos S, Lagerlöf O, Wennergren M, Powell TL, Jansson T: Regulation of amino acid transporters by glucose and growth factors in cultured primary human trophoblast cells is mediated by mTOR singaling. Am J Physiol Cell Physiol 2009, 297:C723-C731.

259. Ghosh S, Lau H, Simons BW, Powell JD, Meyers DJ, De Marzo AM, Berman DM, Lotan TL: PI3K/mTOR signaling regulates prostatic branching morphogenesis. Dev Biol 2011, 360:329-342.

260. Chantaravisoot N, Tamanoi F: mTOR signaling and human cancer. The Enzymes 2010, 28:301-316.

261. Li L, Ittmann MM, Ayala G, Tsai MJ, Amato RJ, Wheeler TM, Miles BJ, Kadmon D, Thompson TC: The emerging role of the PI3-K-Akt pathway in prostate cancer progression. Prostate Cancer Prostatic Dis 2005, 8:108-118.

262. Tolcher AW: Novel therapeutic molecular targets for prostate cancer: the mTOR signaling pathway and epidermal growth factor receptor. J Urol 2004, 171:S41-S44.

263. Morgan TM, Koreckij TD, Corey E: Targeted therapy for advanced prostate cancer: inhibition of the PI3K/Akt/mTOR pathway. Curr Cancer Drug Target 2009, 9:237-249.

264. Mazzoletti M, Bortolin F, Brunelli L, Pastorelli R, Di Giandomenico S, Erba E, Ubezio P, Broggini M: Combination of PI3K/mTOR inhibitors: Antitumor activity and molecular correlates. Cancer Res 2011, 71:4573-4584.

265. Wang Y, Kresiberg Jl, Ghosh PM: Cross-talk between the androgen receptor and the phosphatidylinositol 3-kinase/Akt pathway in prostate cancer. Curr Cancer Drug Targets 2007, 7:591-604.

266. Parkin DM: The fraction of cancer attributable to lifestyle and environmental factors in the UK in 2010. Br J Cancer 2011, 105:S2-S5.

267. Ross RK, Henderson BE: Do diet and androgens alter prostate cancer risk via a common etiologic pathway? J Nat Cancer Inst 1994, 86:252-254.

268. Cordain L, Eades MR, Eades MD: Hyperinsulinemic diseases of civilization: more than just Sysdrome X. Comp Biochem Physiol A Mol Integr Physiol 2003, 136:95-112.

269. Eaton SB, Konner M: Paleolithic nutrition. A consideration of its nature and current implications. N Engl J Med 1985, 312:283-289.

270. Brand-Miller J: Origins and evolution of the Western diet: health implications for the $21^{\text {st }}$ century. Am J Clin Nutr 2005, 81:341-354.

271. Carrera-Bastos P, Fontes-Villalba M, O'Keefe JH, Lindeberg S, Cordain L: The western diet and lifestyle and diseases of civilization. Res Rep Clin Cardiol 2011, 2:15-35.

272. Bryder L: From breast to bottle: a history of modern infant feeding. Endeavour 2009, 33:54-59.

273. Melnik BC: Androgen abuse in the community. Curr Opin Endocrinol Diabetes Obes 2009, 16:218-223.

doi:10.1186/1743-7075-9-74

Cite this article as: Melnik et al:: The impact of cow's milk-mediated mTORC1-signaling in the initiation and progression of prostate cancer. Nutrition \& Metabolism 2012 9:74.

\section{Submit your next manuscript to BioMed Central and take full advantage of:}

- Convenient online submission

- Thorough peer review

- No space constraints or color figure charges

- Immediate publication on acceptance

- Inclusion in PubMed, CAS, Scopus and Google Scholar

- Research which is freely available for redistribution

Submit your manuscript at www.biomedcentral.com/submit 